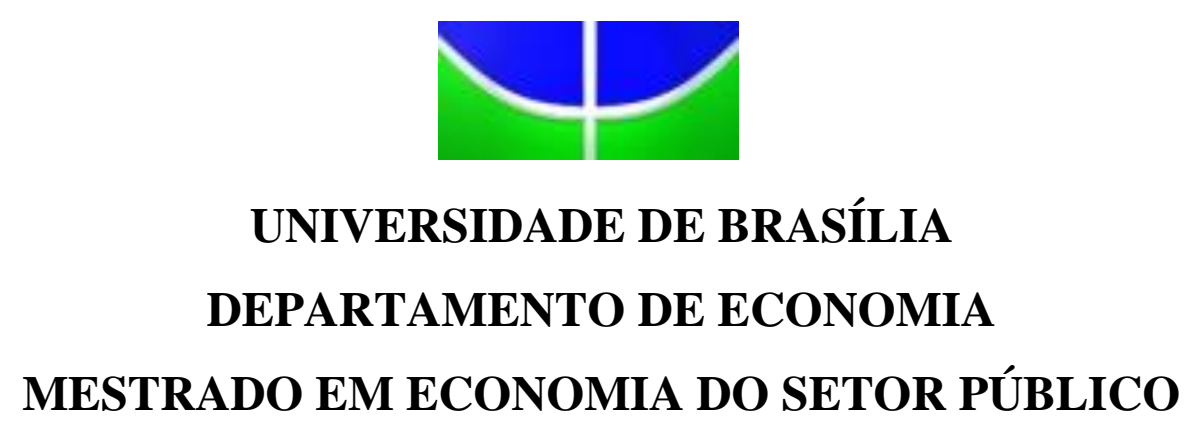

Daniel Veloso Couri

UMA ANÁLISE DE SUSTENTABILIDADE DA DÍVIDA PÚBLICA BRASILEIRA 


\author{
Daniel Veloso Couri
}

\title{
UMA ANÁLISE DE SUSTENTABILIDADE DA DÍVIDA PÚBLICA BRASILEIRA
}

Dissertação de Mestrado apresentada ao Departamento de Economia da Universidade de Brasília como requisito para obtenção do título de Mestre em Economia do Setor Público.

Orientador: Prof. Dr. Paulo Springer de Freitas

Brasília 


\section{AGRADECIMENTOS}

Ao meu professor e orientador Paulo Springer, pela generosidade e disposição na transmissão do conhecimento. 


\section{Resumo}

O presente estudo busca avaliar a sustentabilidade da dívida pública brasileira no médio prazo, com base em projeções estocásticas para o comportamento das principais variáveis que afetam a dinâmica da dívida. Nesse sentido, busca superar uma das principais limitações da abordagem prospectiva tradicional, baseada em cenários determinísticos, que falha em considerar adequadamente a incerteza subjacente ao comportamento das variáveis macroeconômicas. A metodologia adotada tem a vantagem adicional de se permitir que a análise seja estruturada em torno de um cenário-base independente, ao invés da extração direta do valor das variáveis ao longo do período preditivo. Essa possibilidade parece cair bem no contexto brasileiro atual, dado que as condições fiscais de momento levam claramente a trajetórias insustentáveis da dívida. A metodologia também tem suas limitações, sendo a principal delas o fato de não prever uma função de reação fiscal, o que permitiria, por exemplo, modelar medidas fiscais de estabilização em face de um choque negativo no PIB ou na taxa de juros. Diferente da maioria dos trabalhos aplicados à dívida brasileira, optou-se por analisar dinâmica da dívida bruta. Além de a dívida bruta ser o principal indicador de sustentabilidade para efeito de comparação internacional, a análise da dívida líquida não revela adequadamente as mudanças de composição e magnitude dos ativos e passivos do setor público. As projeções estocásticas para a dívida bruta brasileira mostram que, mesmo em face de um ajuste fiscal e de uma recuperação gradual da economia, a probabilidade de que em 2021 a relação dívida bruta/PIB seja superior ao patamar de 2016 é de 87,6\%, sendo que a probabilidade de que nesse período a dívida ultrapasse $100 \%$ do PIB é de $15 \%$. Sob a hipótese de choques permanentes na taxa real de juros, a probabilidade de que a dívida em 2021 seja superior à atual continua elevada, 86,4\%, ao passo que a probabilidade de que ela extrapole os $100 \%$ do PIB chega a $30,8 \%$.

Palavras-chave: dívida pública, sustentabilidade fiscal, choques estocásticos, simulações de Monte Carlo. 


\begin{abstract}
The present study evaluates the sustainability of Brazilian debt in the medium term, based on stochastic projections for the main variables that affect the debt dynamics. In this sense, we seek to overcome one of the main limitations regarding the conventional approach, which fails to consider the uncertainty underlying the behavior of macroeconomic variables. The methodology has the additional advantage of allowing the analysis to be structured around an independent baseline scenario, instead of directly extracting the values of the variables over the predictive period. This seems to fall right in the current Brazilian context, given that fiscal conditions at present clearly leads to unsustainable debt paths. The methodology also has its limitations, being the main one the fact it does not take into account a fiscal reaction function, which would allow, for example, stabilization measures to be set forth in the face of a negative shock on GDP or interest rate. Unlike most studies applied to Brazilian debt, we decided to analyze the dynamics of gross debt. Besides the fact that gross debt is the most common sustainability indicator for the purposes of international comparison, the analysis of net debt does not adequately unfolds the changes in size and composition of public sector assets and liabilities. Stochastic projections for Brazilian gross debt show that, even in the face of a fiscal adjustment and a gradual recovery of the economy, the probability that in 2021 the gross debt ratio will be higher than its 2016 level is $87.6 \%$, and the probability that it exceeds 100 percent of GDP is $15 \%$. Under the hypothesis of permanent shocks in real interest rate, the probability of a debt ratio above its current level is still high, $86.4 \%$, whereas the likelihood that it exceeds 100 percent of GDP reaches $30.8 \%$.
\end{abstract}

Keywords: public debt, fiscal sustainability, stochastic shocks, Monte Carlo simulation. 


\section{Sumário}

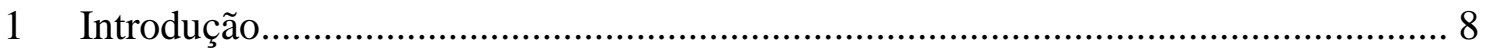

2 Evolução recente do endividamento público brasileiro ....................................... 10

2.1 Dívida pública brasileira em perspectiva comparada ...........................................10

2.2 Evolução recente da dívida e seus principais componentes ...................................14

2.3 Fatores condicionantes da evolução recente da dívida pública ..............................20

3 A literatura sobre sustentabilidade fiscal ...................................................... 25

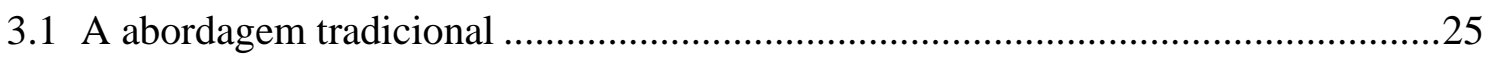

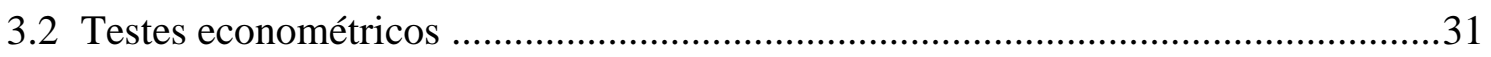

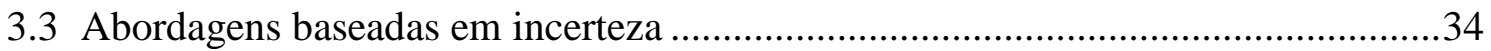

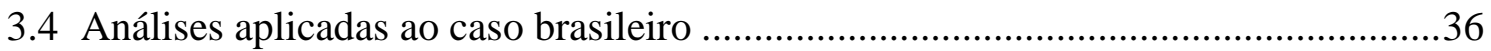

4 Abordagem estocástica de médio prazo para a dívida pública............................... 41

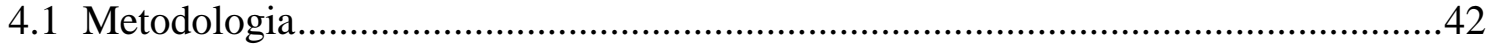

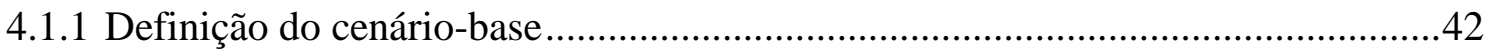

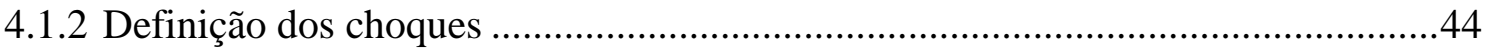

4.1.3 Simulações de Monte Carlo .............................................................................46

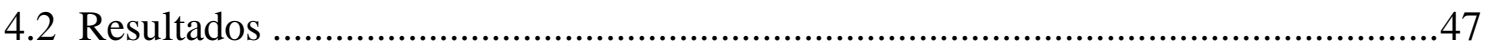

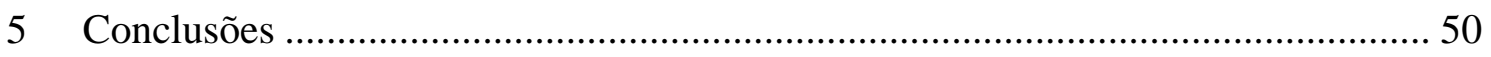

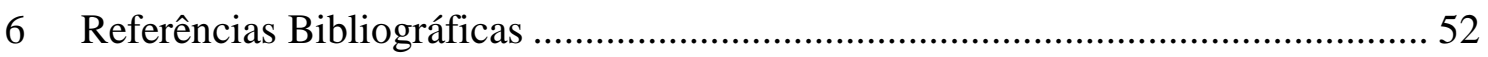




\section{Lista de Figuras}

Figura 1 - Dívida bruta do governo geral e juros nominais líquidos em 2015 (\% do PIB) 13

Figura 2 - Evolução da DBGG e da DLSP (em \% do PIB) ${ }^{1}$

Figura 3 - Fatores condicionantes da evolução da dívida ${ }^{1}$........................................................ 21

Figura 4 - Evolução hipotética da dívida sem ajustes patrimoniais e metodológicos.......................... 23

Figura 5 - Evolução da dívida bruta do governo geral - Cenário-base (\% PIB) ................................ 44

Figura 6 - Projeções para a dívida bruta do governo geral - choques temporários ...........................47

Figura 7 - Projeções para a dívida bruta do governo geral - choques permanentes .........................48

\section{Lista de Tabelas}

Tabela 1 - Principais componentes da DBGG e da DLSP (em \% do PIB) ....................................... 15

Tabela 2 - Hipóteses macroeconômicas - cenário-base..............................................................44

Tabela 3 - Matriz de variância e covariância dos choques ............................................................45

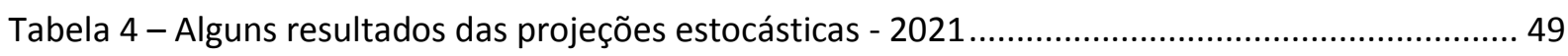




\section{Introdução}

A sustentabilidade fiscal é tema corriqueiro na literatura sobre política fiscal e finanças públicas. Naturalmente, para determinado país ou grupo de países, eventos que levem a uma ruptura no padrão de endividamento ou à reversão de trajetórias decrescentes de dívida costumam atrair uma maior atenção de especialistas e órgãos governamentais.

Trata-se, por exemplo, do caso dos países da zona do euro no período pós-eclosão da crise financeira de 2008-2009, alguns dos quais se viram rapidamente com níveis de endividamento preocupantes. É o caso também do Brasil, embora com alguns anos de atraso em relação aos países europeus. Com efeito, o país nos últimos dois anos reverteu uma trajetória de endividamento até então decrescente, em termos de dívida líquida, ou relativamente estável, em termos de dívida bruta.

Influenciam o número de trabalhos sobre sustentabilidade da dívida não apenas episódios de crise, mas também desafios fiscais de médio e longo prazos, os quais são compartilhados pela maioria dos países. O principal deles é a pressão fiscal exercida pelo envelhecimento da população, com repercussão mais direta sobre as despesas com previdência e saúde, mas que impacta inclusive a capacidade arrecadatória dos governos.

O arranjo fiscal que sucedeu a edição da Lei de Responsabilidade Fiscal foi, de certa forma, capaz de ancorar as expectativas quanto à trajetória da dívida pública brasileira, historicamente caracterizada pela persistência de déficits públicos e juros elevados. Com arrecadação crescente e geração de sucessivos superávits primários, o endividamento público brasileiro (em proporção PIB) reduziu-se entre os anos de 2006 e 2013. Isso a despeito dos juros ainda elevados, quando comparados com outros países, e do crescimento da despesa pública.

Em pouco mais de dois anos e meio, entre o final de 2013 e julho de 2016, a dívida bruta passou de $51,7 \%$ para $69,6 \%$ do PIB, enquanto a dívida líquida passou de 30,6\% para $43,3 \%$ do PIB. No mesmo período, os juros nominais pagos sobre a dívida passaram de 4,5\% para $7,1 \%$ do PIB.

Ainda que o cenário fiscal de médio e longo prazos imponha riscos à sustentabilidade da dívida pública brasileira, o debate em torno das finanças públicas no Brasil continua relativamente dominado por avaliações de curto-prazo. Essa miopia fiscal é influenciada, entre outros fatores, pela desobrigação legal de se construírem cenários fiscais de médio e longo 
prazos quando da elaboração das leis orçamentárias. As análises oficiais, em geral, ficam adstritas ao cenário fiscal da lei de diretrizes orçamentárias, que alcança apenas três exercícios.

Entende-se que níveis moderados de endividamento são importantes para garantir espaço fiscal suficiente para se lidar com cenários macroeconômicos adversos e com os custos impostos pelo envelhecimento da população. Dito de outra forma, a condução da política fiscal deve garantir que seja gerada, nos períodos de crescimento, economia fiscal suficiente para ser utilizada em momentos de desaceleração.

Nesse contexto, o presente trabalho tem como objetivo específico avaliar a sustentabilidade da dívida pública brasileira no médio prazo, com base em projeções estocásticas para o comportamento das principais variáveis que afetam a dinâmica da dívida.

Diferente da maior parte da literatura aplicada ao caso brasileiro que costuma examinar a dinâmica da dívida líquida, neste exercício examinaremos a evolução da dívida bruta, principal indicador de sustentabilidade para efeito de comparação internacional. Outro traço distintivo em relação à maioria das abordagens semelhantes é a geração de choques estocásticos em torno de um cenário-base ao invés da extração direta do valor das variáveis ao longo do período preditivo. Tratar os choques dessa forma permite que se analisem possíveis trajetórias para dívida em torno de um contexto de ajuste fiscal, o que parece ser demandado para o caso brasileiro.

Em síntese, essa abordagem permite, por meio de simulações de Monte Carlo, que se construam intervalos de confiança para a dívida pública no médio prazo, a partir dos quais podem ser atribuídas probabilidades para os possíveis valores da dívida no futuro.

Esse tipo de abordagem é inspirado em relatórios de sustentabilidade fiscal atualmente produzidos por diversos países, muitas vezes por parte de instituições fiscais independentes, na esteira das mais recentes recomendações em termos de governança orçamentária. Em particular, o estudo é influenciado pelo relatório trienal da Comissão Europeia, que por sua vez emprega a metodologia adotada inicialmente por Di Giovanni e Gardner (2008).

O trabalho está organizado da seguinte forma. Após esta introdução, o capítulo 2 analisa a evolução recente da dívida pública brasileira, tanto em perspectiva comparada quanto em termos de sua composição e dos fatores que condicionam sua dinâmica. Em seguida, o capítulo 3 traz a revisão da literatura sobre sustentabilidade fiscal, buscando destacar trabalhos seminais dentro das principais abordagens sobre o tema. O capítulo 4, enfim, traz a análise estocástica de médio prazo para a dívida brasileira. O capítulo 5 conclui o trabalho. 


\section{Evolução recente do endividamento público brasileiro}

A evolução recente do endividamento público brasileiro trouxe novamente à baila o debate acerca da sustentabilidade fiscal no país, em certa medida adormecido na primeira década do século. Com efeito, nos primeiros anos que sucederam à edição da Lei de Responsabilidade Fiscal (LRF), tanto o governo federal quanto os governos subnacionais foram capazes de acumular sucessivos superávits primários e, como resultado, reduzir o endividamento do governo geral quando considerada em proporção do PIB.

Tal movimento ocorreu mesmo a despeito de dois fatores historicamente presentes na dinâmica das finanças públicas do país, quais sejam as elevadas taxas de juros pagas sobre o estoque da dívida pública e o crescimento persistente das despesas primárias. Nesse contexto, a geração de superávits primários, no período, foi, em regra, uma função do crescimento da receita pública (este impulsionado pela expansão da atividade econômica), mais do que propriamente de um esforço fiscal empreendido pelo governo.

Contudo, o esgotamento do ciclo de crescimento econômico, em especial a partir de 2011, colocou em evidência a fragilidade do aparente rigor fiscal observado no período anterior. Sem aumentos expressivos de arrecadação, mas ainda presentes as altas taxas de juros e o crescimento da despesa primária, a dívida pública reverteu a trajetória de queda e passou a crescer de forma acelerada, atingindo rapidamente os patamares observados no início da década passada.

Este capítulo explora alguns dos aspectos relacionados à evolução recente do endividamento brasileiro.

\subsection{Dívida pública brasileira em perspectiva comparada}

Na raiz do problema fiscal há não apenas fatores tipicamente domésticos, mas também outros compartilhados com o resto do mundo. De fato, a sustentabilidade das finanças públicas é um tema atual para grande parte dos países. De acordo com Sarvi et al. (2011), isso se explica por duas questões principais. Em primeiro lugar, pela expressiva elevação da dívida pública de alguns países no rescaldo da crise financeira de 2008, que trouxe, como consequência, a exigência de rendimentos cada vez mais altos pelo mercado para compensar o risco adicional. 
Em segundo lugar, numa perspectiva de longo prazo, a sustentabilidade fiscal de grande parte economias está ameaçada pela mudança demográfica e seus desdobramentos em termos de gasto público, em particular os relacionados a previdência e saúde.

Cabe observar, na esteira de Comissão Europeia (2016), que, enquanto a dívida pública não fosse um dos motivos da crise financeira de 2008-2009, na maioria dos países a falta de espaço fiscal inicial impediu o uso adequado das medidas fiscais e essas economias atualmente encaram níveis de dívida pública mais elevados devido às consequências da crise. Esse efeito foi especialmente sentido em algumas economias avançadas, tais como Portugal, Grécia, Itália e Estados Unidos.

Sobre a distinção entre os impactos de períodos recessivos em economias avançadas e emergentes, Garcia e Rigobon (2004) enfatiza que, no primeiro caso, recessões (ou períodos de crescimento inferior) são geralmente acompanhadas por uma diminuição na taxa de juros (política monetária expansionista). Neste caso, a recessão e a deterioração do resultado primário - que prejudicam a sustentabilidade da dívida - são acompanhadas de uma redução na taxa de juros - que reduz o impacto negativo sobre a dívida. Haveria, portanto, um estabilizador automático na dinâmica do endividamento. Por outro lado, em economias emergentes, geralmente a recessão deteriora as contas públicas, aumenta a taxa real de juros, induz a inflação e deprecia a taxa de câmbio, o que, combinados, potencializam a elevação da dívida pública.

Essas considerações - espaço fiscal para adoção de medidas em resposta a crises e efeitos de períodos recessivos em economias avançadas e emergentes - podem ser brevemente analisadas à luz do caso brasileiro.

A dívida bruta do governo geral no advento da crise financeira de 2008 se situava em patamar próximo a $62 \%$ do PIB, abaixo da média das principais economias. É possível argumentar que havia, à época, espaço fiscal suficiente para a adoção de medidas anticíclicas em resposta à crise. De fato, em 2009 houve uma queda do superávit primário e a dívida subiu para $64,9 \%$ do PIB, retornando nos dois anos seguintes para o patamar de $61 \%$. Além disso, após uma queda de 0,1\% em 2009, o PIB cresceu 7,5\% e 3,9\% em 2010 e 2011, respectivamente.

O que se observou a partir de 2013 , em contraste, foi a deterioração do resultado primário, elevação do nível de preços, aumento da taxa real de juros, depreciação cambial e crescimento da dívida, tal qual enfatizara Garcia e Rigobon (2004). Pode-se questionar, portanto, se o uso das medidas anticíclicas adotadas em 2009, embora eficazes no rescaldo da crise financeira, terminou por ser ele próprio o causador da crise fiscal doméstica que se viu no momento seguinte. Em 2015, a dívida bruta do governo geral (DBGG) chegou a 73,4\% do PIB, 
segundo metodologia do Fundo Monetário Internacional (FMI), e o pagamento líquido de juros nominais somou $8,5 \%$ do PIB.

Neste ponto, cabe mencionar a distinção metodológica entre o conceito de DBGG adotado pelo FMI, aqui usado para efeito de comparação entre os países, e aquele utilizado pelo Banco Central do Brasil (Bacen). A DBGG no conceito FMI inclui a dívida mobiliária do Tesouro em poder do mercado e também aquela em poder do Bacen, ou seja, inclui toda a posição de títulos públicos no ativo do Bacen. Já a DBGG no conceito brasileiro inclui a dívida mobiliária do Tesouro em poder do mercado e somente a parcela da dívida em poder do Bacen que seja utilizada em operações compromissadas, excluindo a carteira livre do Bacen (aquela que não é lastro de operações compromissadas).

Gobetti e Schettini (2010) analisa que, apesar da divergência conceitual, a metodologia atualmente adotada no Brasil permite melhores comparações intertemporais da dívida bruta no país, uma vez que até 2002 o próprio Bacen era responsável por emitir os títulos utilizados na administração da base monetária. Neste caso, pela convenção internacional, tais títulos não deveriam compor o cálculo da dívida bruta, dado que o banco não faz parte do governo geral.

A partir de 2002, por força da LRF, o Bacen não pode mais emitir títulos públicos e o Tesouro passou a emitir títulos e transferi-los para a autoridade monetária utilizá-los em operações compromissadas. Como a dívida mobiliária do Tesouro está dentro da abrangência do governo geral, os novos títulos passaram inicialmente a integrar a DBGG. Em 2008, o Bacen alterou sua metodologia para que apenas os títulos na carteira do Bacen que estivessem sendo usados em operações compromissadas fossem computados na DBGG .

Nesse sentido, os autores defendem que, do ponto de vista econômico, a nova metodologia de cálculo da DBGG parece mais adequada para mensurar o efetivo endividamento do governo geral.

Ferreira (2016), por seu turno, ao analisar a dinâmica da DBGG brasileira, argumenta que o uso do conceito brasileiro da DBGG não mais seria apropriado, já que o elevado saldo das compromissadas e o (consequente) tamanho reduzido da carteira livre do Bacen tornaram pouco relevante a diferença de valor entre elas. Em 2015, no entanto, a DBGG pela metodologia atual do Bacen foi de 66,5\% do PIB, 7,2 p.p. inferior ao valor do FMI, o que parece não confirmar o argumento trazido pelo autor. Entre 2006 e 2010, a diferença média entre os valores foi de 8,1 p.p.

Mendes (2016) alerta para o fato de que, a depender de como o Tesouro decide financiar seu déficit, o conceito brasileiro pode não refletir adequadamente a realidade fiscal. Em acréscimo, o autor aponta o risco de que, diante de uma eventual necessidade de aporte de 
títulos à carteira do Bacen para lastrear operações compromissadas, o Ministério da Fazenda se oponha à transferência para evitar o aumento da DBGG apurada pelo FMI.

Com exceção dos dados apresentados a título de análise comparativa, serão utilizados neste trabalho os valores da DBGG conforme definido pelo Bacen, órgão atualmente responsável pela elaboração das estatísticas fiscais oficiais no âmbito da União.

Em perspectiva comparada, a dívida bruta brasileira se encontra atualmente em patamar próximo ao das principais economias do mundo. Nota-se, contudo, que, entre as economias emergentes mais relevantes, o país é o que possui o maior endividamento, seguido por Índia, Argentina e México, nessa ordem. Como se observa no gráfico 1, que filtra as vinte maiores economias do mundo, o Japão é o país com endividamento mais expressivo, embora, nesse caso, não se possa falar em crise fiscal, dado o baixo custo de carregamento da dívida japonesa.

Figura 1 - Dívida bruta do governo geral e juros nominais líquidos em 2015 (\% do PIB)

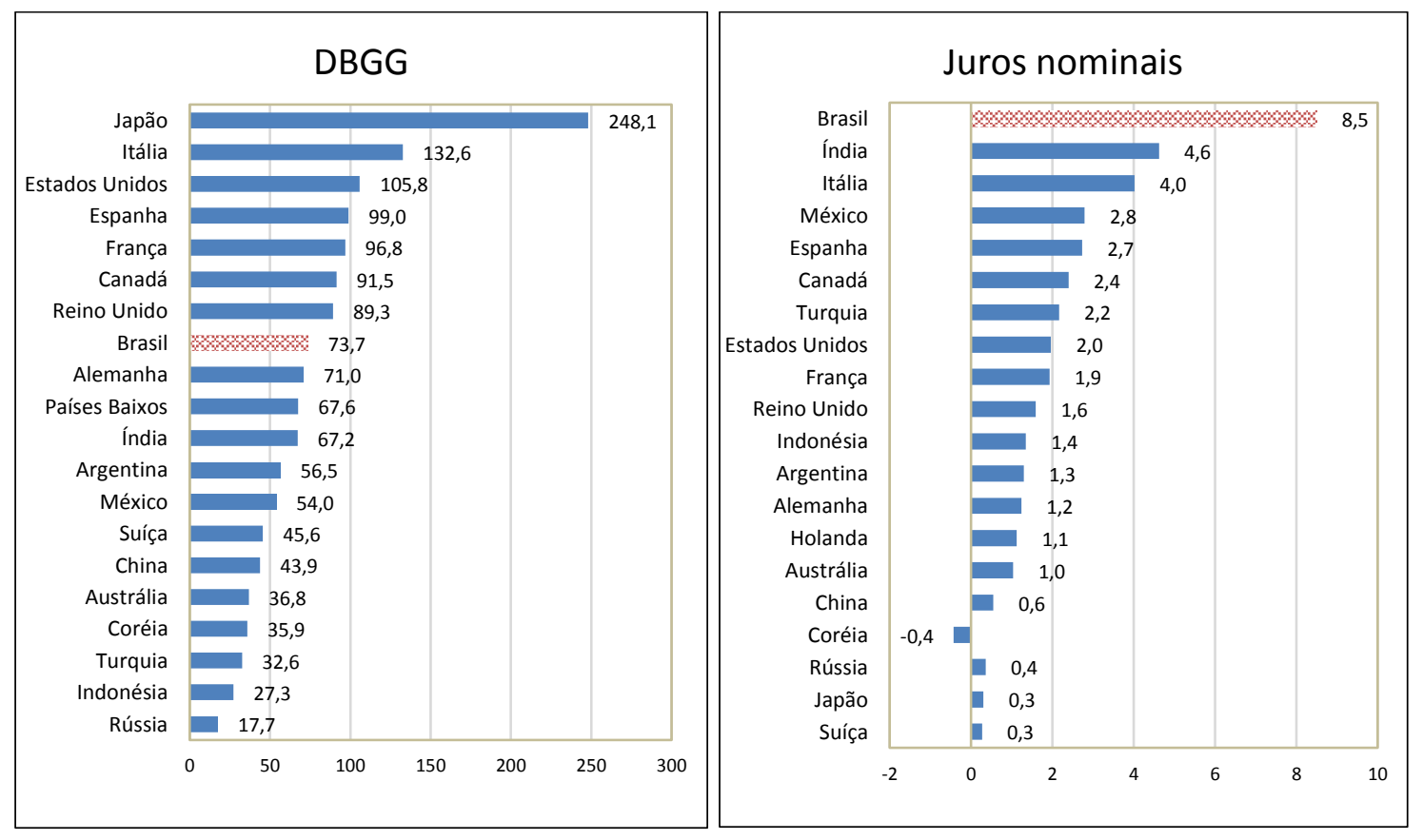

Fonte: Fundo Monetário Internacional e Banco Central do Brasil. Elaboração Própria.

Em relação ao custo de carregamento da dívida, do qual o pagamento líquido de juros nominais é uma boa medida, o Brasil se destaca como o país com maior carga de juros em proporção do PIB entre as economias mais relevantes. Em 2015, os juros nominais líquidos ficaram em 8,5\% do PIB, seguido de longe por Índia (4,6\%) e Itália (4\%).

Essa breve análise comparada reforça que, de fato, o elevado pagamento de juros é uma das principais características distintivas do nosso endividamento, ainda que o estoque atual da dívida bruta não se distinga significativamente da média dos demais países. 


\subsection{Evolução recente da dívida e seus principais componentes}

No Brasil, contudo, o principal indicador utilizado para avaliar a sustentabilidade da dívida pública é a dívida líquida do setor público (DLSP). A DLSP é definida como o balanceamento entre as dívidas e os créditos do setor público não-financeiro e do Bacen. $\mathrm{O}$ setor público não-financeiro compreende a administração direta e indireta dos governos federal (inclusive previdência social), estadual e municipal, bem como as empresas estatais nãofinanceiras (exceto, desde 2009, Petrobras e Eletrobras). Conforme Gobetti e Schettini (2010), por esse conceito, em resumo, obtém-se um balanço do setor público não financeiro em relação aos agentes privados e aos públicos financeiros.

A DBGG, além de não considerar os créditos do setor público, é de abrangência mais restrita, pois compreende apenas os débitos de responsabilidade dos governos federal, estadual e municipal, junto ao setor privado, ao setor público financeiro e ao resto do mundo. Exclui, portanto, os débitos de responsabilidade das empresas estatais e o Bacen.

O gráfico a seguir compara a evolução da DBGG e da DLSP nos últimos dez anos.

Figura 2 - Evolução da DBGG e da DLSP (em \% do PIB) ${ }^{1}$

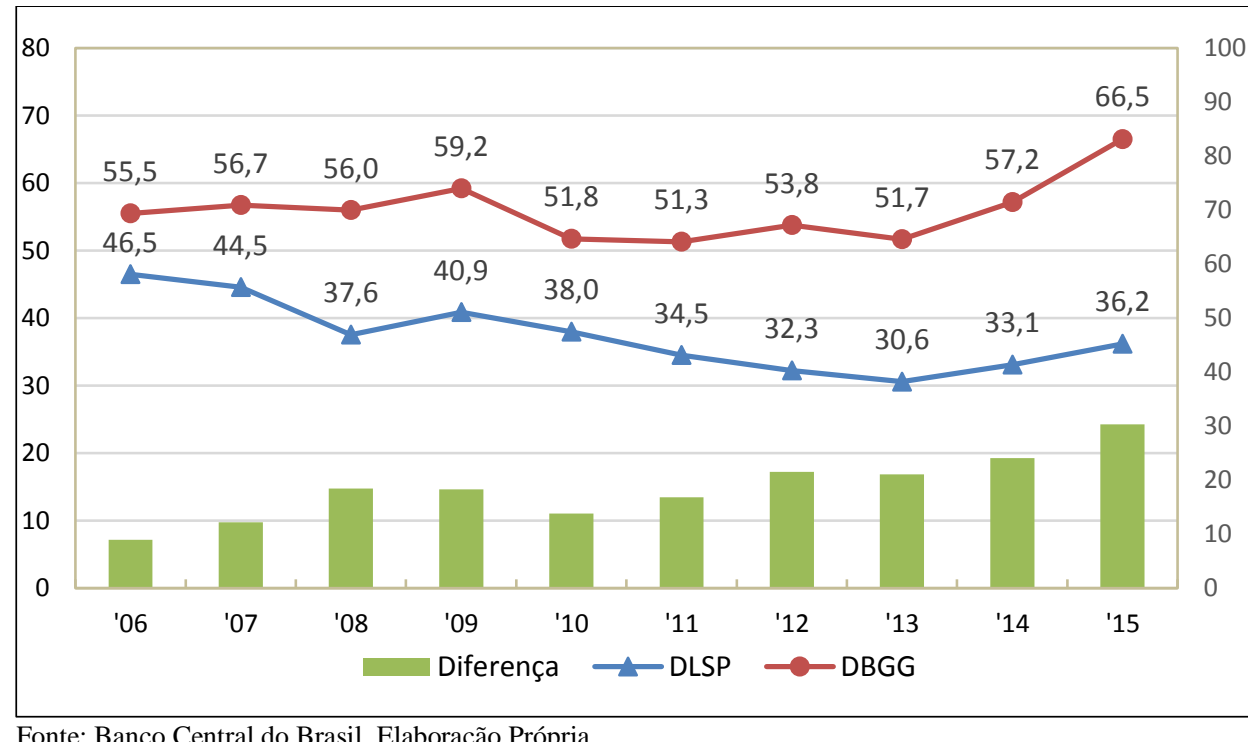

Fonte: Banco Central do Brasil. Elaboração Própria.

${ }^{1} \mathrm{O}$ eixo da direita se refere à diferença entre a DBGG e a DLSP, mostrada nas barras do gráfico.

A dinâmica recente da DBGG e da DLSP tem sido objeto de vários trabalhos nos últimos anos. Em particular, as análises têm focado na relação existente entre os ativos do setor público e o endividamento bruto e suas implicações. Nesta seara, citam-se as contribuições de Mendonça at al. (2016), Schettini (2014), Pellegrini (2011), Gobetti e Schettini (2010) e Almeida (2009). 
A tabela 1 apresenta a evolução recente das dívidas líquida e bruta do setor público, segregada pelos seus principais componentes. As séries podem ser construídas a partir de tabelas disponibilizadas pelo Bacen na internet. Como visto, os indicadores utilizados pelo Banco para efeito de acompanhamento do endividamento - a DLSP e a DBGG - possuem abrangência distinta. Nesse sentido, para uma melhor comparação, foram agregados ao governo geral os ativos e passivos do Bacen, o que nos permite incluir, por exemplo, a base monetária (pelo lado da dívida) e as reservas internacionais (pelo lado dos ativos).

Consequentemente, os débitos e créditos que refletem as relações entre o governo federal e o Bacen não aparecem na tabela. Além disso, as operações compromissadas não estão incluídas no ativo do Banco Central por já serem consideradas no conceito governo geral.

Essa agregação nos permitiria obter, segundo Mendonça et al. (2016), a chamada dívida bruta do setor público (DBSP). Pellegrini (2011), por outro lado, se refere a esse indicador apenas como "DBGG e Bacen", denominação aqui adotada pelo fato de que tal indicador não inclui os passivos das empresas estatais.

Pelo balanceamento entre créditos e débitos do governo geral e Bacen chega-se à dívida líquida do governo geral e Banco Central. Quando incluímos a dívida líquida das empresas estatais (exceto Petrobras e Eletrobrás), obtém-se a DLSP.

Tabela 1 - Principais componentes da DBGG e da DLSP (em \% do PIB)

\begin{tabular}{|c|c|c|c|c|c|c|c|c|c|c|c|c|}
\hline \multirow[b]{2}{*}{ Discriminação } & \multirow[b]{2}{*}{ '06 } & \multirow[b]{2}{*}{ '07 } & \multirow[b]{2}{*}{ '08 } & \multirow[b]{2}{*}{ '09 } & \multirow[b]{2}{*}{ '10 } & \multirow[b]{2}{*}{ '11 } & \multirow[b]{2}{*}{ '12 } & \multirow[b]{2}{*}{ '13 } & \multirow[b]{2}{*}{ '14 } & \multirow[b]{2}{*}{ '15 } & \multicolumn{2}{|c|}{ Variação (p.p.) } \\
\hline & & & & & & & & & & & $\begin{array}{c}06 \text { a } \\
\text { '13 } \\
\end{array}$ & $\begin{array}{l}13 \mathrm{a} \\
\text { '15 } \\
\end{array}$ \\
\hline $\operatorname{DLSP}(A=B+L)$ & 46,5 & 44,5 & 37,6 & 40,9 & 38,0 & 34,5 & 32,3 & 30,6 & 33,1 & 36,2 & $-15,9$ & 5,6 \\
\hline DLGG e Bacen $(B=C-H)$ & 45,6 & 43,7 & 36,8 & 40,2 & 37,4 & 33,9 & 31,7 & 30,0 & 32,4 & 35,3 & $-15,6$ & 5,3 \\
\hline DBGG e Bacen $(C=D+G)$ & 64,0 & 65,8 & 63,1 & 66,0 & 65,1 & 64,6 & 64,3 & 63,0 & 67,2 & 77,3 & $-1,0$ & 14,4 \\
\hline Dívida interna $(\mathrm{D}=\mathrm{E}+\mathrm{F})$ & 57,7 & 61,5 & 58,4 & 62,7 & 62,3 & 62,1 & 61,6 & 60,1 & 63,9 & 72,9 & 2,4 & 12,8 \\
\hline Governo geral (E) & 49,2 & 52,4 & 51,3 & 55,9 & 49,0 & 48,8 & 51,1 & 48,9 & 53,9 & 62,1 & $-0,4$ & 13,2 \\
\hline Dívida mobiliária federal em mercado & 44,6 & 44,3 & 39,8 & 41,1 & 40,4 & 39,9 & 38,9 & 37,4 & 37,6 & 44,2 & $-7,1$ & 6,8 \\
\hline Operações compromissadas & 3,2 & 6,9 & 10,5 & 13,6 & 7,4 & 7,8 & 10,9 & 9,9 & 14,2 & 15,5 & 6,7 & 5,5 \\
\hline Outras contas & 1,5 & 1,3 & 1,1 & 1,1 & 1,1 & 1,1 & 1,2 & 1,5 & 2,0 & 2,4 & 0,0 & 0,9 \\
\hline Bacen (F) & 8,5 & 9,1 & 7,1 & 6,8 & 13,4 & 13,3 & 10,5 & 11,3 & 10,1 & 10,8 & 2,7 & $-0,4$ \\
\hline Base monetária & 5,0 & 5,4 & 4,7 & 5,0 & 5,3 & 4,9 & 4,9 & 4,7 & 4,6 & 4,3 & $-0,3$ & $-0,4$ \\
\hline Depósitos no Bacen & 3,5 & 3,8 & 1,8 & 1,9 & 8,1 & 8,5 & 5,7 & 5,9 & 5,0 & 5,7 & 2,4 & $-0,2$ \\
\hline Outras contas & 0,0 & $-0,1$ & 0,6 & $-0,1$ & $-0,1$ & $-0,1$ & $-0,1$ & 0,7 & 0,4 & 0,8 & 0,7 & 0,1 \\
\hline Dívida externa (G) & 6,2 & 4,3 & 4,7 & 3,3 & 2,8 & 2,5 & 2,7 & 2,8 & 3,3 & 4,4 & $-3,4$ & 1,6 \\
\hline Ativo do governo geral e Bacen $(\mathrm{H}=\mid+\mathrm{J}+\mathrm{K})$ & 18,4 & 22,1 & 26,3 & 25,8 & 27,7 & 30,7 & 32,6 & 32,9 & 34,8 & 42,0 & 14,6 & 9,1 \\
\hline Créditos da União às instituições oficiais (I) & 0,5 & 0,5 & 1,4 & 4,3 & 6,6 & 7,3 & 8,5 & 8,8 & 9,6 & 9,6 & 8,3 & 0,8 \\
\hline Reservas internacionais $(\mathrm{J})$ & 7,6 & 11,7 & 15,5 & 12,2 & 12,2 & 14,9 & 15,7 & 16,4 & 17,3 & 24,1 & 8,8 & 7,8 \\
\hline Outros ativos internos $(\mathrm{K})$ & 10,2 & 9,8 & 9,4 & 9,2 & 9,0 & 8,5 & 8,4 & 7,8 & 8,0 & 8,3 & $-2,4$ & 0,5 \\
\hline Disponibilidades do governo geral & 0,9 & 1,1 & 1,2 & 1,2 & 1,2 & 1,2 & 1,3 & 1,3 & 1,2 & 1,1 & 0,5 & $-0,3$ \\
\hline Aplicações em fundos e programas & 2,1 & 2,0 & 2,0 & 2,2 & 2,5 & 2,3 & 2,4 & 2,2 & 2,4 & 2,6 & 0,1 & 0,4 \\
\hline
\end{tabular}




\begin{tabular}{lllllllllllll} 
Recursos do FAT na rede bancária & 5,1 & 4,7 & 4,4 & 4,2 & 3,8 & 3,6 & 3,6 & 3,5 & 3,6 & 3,8 & $-1,6$ & 0,4 \\
Créditos do Bacen às inst. financeiras & 0,8 & 0,9 & 0,9 & 0,8 & 0,8 & 0,8 & 0,8 & 0,5 & 0,4 & 0,4 & $-0,3$ & $-0,1$ \\
Outras contas & 1,4 & 1,1 & 1,0 & 0,8 & 0,7 & 0,5 & 0,4 & 0,3 & 0,4 & 0,4 & $-1,0$ & 0,1 \\
Dívida líquida das empresas estatais (L) & 0,8 & 0,8 & 0,8 & 0,7 & 0,6 & 0,6 & 0,6 & 0,6 & 0,7 & 0,9 & $-0,3$ & 0,3 \\
\hline
\end{tabular}

Fonte: Banco Central do Brasil. Elaboração Própria.

A tabela evidencia dois movimentos distintos na evolução recente da DLSP. De 2006 a 2013, ela cai de forma acentuada, passando de 46,5\% para 30,6\% do PIB. A partir de 2013, essa tendência se reverte e a dívida líquida cresce em dois anos 5,6 p.p., chegando a 36,2\% do PIB ao final de 2015.

No primeiro período, o que se observa é uma queda da dívida líquida causada principalmente pelo aumento de ativos do setor público, dado que o endividamento bruto teve pequena variação. O aumento dos ativos, por sua vez, está relacionado: (1) ao acúmulo de reservas internacionais; e (2) à concessão de empréstimos pela União a instituições financeiras oficiais, em especial ao Banco Nacional de Desenvolvimento Econômico e Social (BNDES). Embora a dívida bruta não tenha crescido, houve uma mudança de composição, caracterizada por: (1) troca de dívida externa por dívida interna; e (2) aumento das operações compromissadas do Bacen.

Há, em resumo, uma notória variação quantitativa e qualitativa dos ativos do setor público, combinada com uma mudança de feição apenas qualitativa dos passivos, cujo resultado é a redução do endividamento líquido, mas com repercussão na estrutura de rendimentos e na trajetória futura desse indicador. Tal transição é analisada a seguir.

As reservas internacionais passaram de 7,6\% (US\$ 85,8 bilhões) em dezembro de 2006 para 16,4\% do PIB (US\$ 358,8 bilhões) em dezembro de 2013. Para Gobetti e Schettini (2010), o crescimento expressivo dos ativos em moeda estrangeira no período foi resultado, inicialmente, de uma estratégia de proteção contra crises cambiais e, posteriormente, de um esforço do governo em conter a apreciação do real, diante da entrada de capital no país.

A estratégia de contenção da valorização do real permitiu também o resgate de grande parte da dívida pública externa. Entre 2006 e 2013, a dívida externa caiu de 6,2\% para 2,8\% do PIB. A queda da dívida externa, a rigor, tem início ainda em 2003, quando os passivos externos se situavam em patamar próximo a $19 \%$ do PIB. Em face dos saldos positivos no balanço de pagamentos verificados a partir desse ano, o Tesouro passou a emitir títulos da dívida interna para adquirir divisas e recomprar os títulos da dívida externa.

Pellegrini (2011) chama atenção para o custo de se manterem ativos em moeda estrangeira. Tradicionalmente boa parte desses ativos está aplicada em papéis soberanos de 
baixo risco, que rendem muito pouco em relação a outros ativos financeiros no Brasil. Dessa forma, a variável fundamental para aferir os rendimentos das reservas se torna a própria variação cambial.

Enquanto a valorização do câmbio gera perdas para as contas públicas, a desvalorização seguinte tenderá a reverter o dano. Entretanto, essa reversão poderá não se concretizar caso o governo se desfaça das reservas para impedir uma desvalorização cambial mais acentuada. Nessa configuração, o autor adverte que o resultado final mais provável é o aumento do déficit público resultante do custo líquido de carregamento das reservas.

Por outro lado, Gobetti e Schettini (2010) lembra que a troca de dívida externa por dívida interna evita, na ocorrência de choques cambiais, o risco de elevação da dívida em magnitude que impeça o governo de adotar políticas anticíclicas.

O acúmulo de reservas internacionais é também um dos principais fatores condicionantes do crescimento das operações compromissadas entre 2006 e 2013. O aumento dessas operações, contudo, teve como principal determinante o resgate líquido de títulos pelo Tesouro Nacional ao longo desses anos (BACEN, 2015).

Com efeito, para conter a expansão da base monetária gerada pela aquisição de divisas externas ou pelo resgate de títulos públicos, o Bacen realiza operações compromissadas como forma de restringir a liquidez da economia. Como resultado, o saldo de operações compromissadas saltou de 3,2\% para 9,9\% do PIB no período.

Vale mencionar, em contraste, estudo do Banco Central (2015) que aponta que, entre 2007 e 2015, o maior fator de expansão das operações compromissadas teria sido o resgate líquido de títulos pelo Tesouro Nacional e não a aquisição de reservas internacionais ou o pagamento de swaps cambiais.

Em acréscimo, deve-se observar que o desempenho positivo da economia no período ainda permitiu que a gestão da dívida pelo Tesouro Nacional fosse capaz de reduzir a parcela da dívida indexada ao câmbio e à taxa Selic, aumentando a participação de prefixados e indexados a índices de preços, além de alongar o prazo médio da dívida.

Por fim, outra mudança significativa na dívida pública se deu com a concessão de empréstimos pela União a instituições financeiras oficiais, principalmente ao BNDES, cuja motivação inicial foi a necessidade de adoção de medidas anticíclicas em resposta à crise internacional de 2008-2009. Entre 2008 e 2013, esse componente do ativo do setor público saltou de 1,4\% para 8,8\% do PIB (linha I da tabela 1). Em valores absolutos, o salto no período foi de R\$ 43,1 bilhões para R \$ 466,9 bilhões. Do total ao final de 2013, R\$ 413,0 bilhões representam créditos junto ao BNDES. 
As operações envolvendo a concessão de empréstimos ao BNDES obedeceram, em regra, ao seguinte esquema. O Tesouro Nacional emitiu títulos públicos que foram repassados diretamente ao BNDES, em troca de crédito equivalente para o Tesouro junto ao banco. Esse movimento, por si só, não altera a dívida líquida do setor público, uma vez que houve uma elevação de um passivo do governo geral (dívida mobiliária) e um correspondente aumento de seu ativo (crédito da União às instituições federais, no caso, ao BNDES). Isso porque, como visto, o BNDES faz parte do setor público financeiro e, portanto, não é incluído nas estatísticas fiscais.

Ocorre que, grosso modo, o rendimento médio do ativo segue a Taxa de Juros de Longo Prazo (TJLP), enquanto os títulos públicos são corrigidos pela taxa Selic ou por taxas prefixadas, muito superiores à TJLP. Dito de outra forma, o passivo da União associado a esses empréstimos cresce a uma taxa mais elevada que o ativo correspondente. Dessa forma, embora a operação, num primeiro momento, seja neutra em relação à dívida líquida, no momento seguinte ela passa a ter necessariamente um custo fiscal via diferencial de juros nominais. Se esse custo fiscal não for compensado pela economia primária do governo federal, haverá impacto negativo sobre a dívida líquida do setor público.

Tal impacto tende a ser maior em conjunturas econômicas desfavoráveis, como a atual, pois tanto o custo de carregamento da dívida tende a aumentar, quanto mais difícil se torna a geração de superávits primários, dado o efeito negativo da queda da atividade econômica sobre a arrecadação tributária.

Vale mencionar, como parêntese, que o custo fiscal aqui analisado corresponde ao subsídio creditício (implícito) envolvido na operação. Do ponto de vista da política pública subjacente a esses empréstimos, considerada em todas as suas etapas, há ainda o subsídio financeiro (explícito) gerado quando os recursos são emprestados pelo BNDES ao mutuário final, cuja equalização é de responsabilidade da União. Enquanto o subsídio creditício impacta a dívida líquida via pagamento de juros nominais, o subsídio financeiro a impacta via resultado primário, pois se materializa por meio de despesa primária constante do orçamento da União.

De acordo com o Tesouro Nacional (2016), no segundo bimestre de 2016 o valor presente dos subsídios projetados relativo às operações do Tesouro Nacional com o BNDES era de R \$ 200,1 bilhões, sendo R \$ 175,0 bilhões de subsídios creditícios (empréstimos da União ao BNDES) e R \$ 25,1 bilhões de subsídios financeiros (empréstimos do BNDES ao mutuário final).

Em síntese, pode-se dizer que, entre 2006 e 2013, ocorre uma profunda mudança na composição patrimonial no setor público, caracterizada pelo crescimento dos ativos e relativa 
estabilização da dívida bruta, do que decorre a redução observada na dívida líquida do setor público. Tal dinâmica evidencia que os sucessivos superávits primários ocorridos no período não foram utilizados para reduzir a dívida bruta, mas para financiar a aquisição de ativos financeiros.

As mudanças de composição e magnitude nos indicadores da dívida pública no Brasil entre 2006 e 2013 foram possíveis por conta do desempenho da economia em boa parte desse período. A razoável estabilidade de preços e o crescimento relativamente elevado do PIB serviram de pano de fundo para que a transformação se desse sem comprometer o nível de endividamento e a percepção sobre a sustentabilidade fiscal do país.

O que se observa entre 2013 e 2015, contudo, é uma reversão da trajetória de queda da dívida líquida, que apenas no biênio passou de 30,6\% para 36,2\% do PIB. Esse aumento decorre do expressivo crescimento dos passivos do setor público, em particular da dívida mobiliária e do saldo de operações compromissadas, apenas parcialmente compensado pelo crescimento dos ativos.

Assim como o comportamento dos indicadores de endividamento até 2013 foi influenciado pelo desempenho da economia, a reversão da trajetória da dívida líquida, bem como o crescimento acentuado da dívida bruta, por seu turno, reflete em boa medida a crise econômica atual. Com efeito, em um ambiente com pressão inflacionária, elevação dos juros e queda da atividade econômica, o que se verifica, a um só tempo, é o aumento da conta de juros sobre o estoque da dívida e a deterioração do resultado primário do setor público.

Em 2014 e 2015, houve déficits primários da ordem de 0,6\% e 1,9\% do PIB, respectivamente, e o pagamento líquido de juros nominais passou de 5,5\% para 8,5\% do PIB. A soma desses termos corresponde ao déficit nominal e evidencia a necessidade de financiamento do setor público no exercício, a qual ficou em 6,1\% e 10,4\% do PIB no biênio.

Em linhas gerais, o governo pode financiar seus déficits por meio de emissão monetária, aumento do endividamento ou diminuição de ativos, ou qualquer combinação dessas medidas. A emissão de moeda é considerada uma fonte indesejável, dado o efeito inflacionário que pode ser gerado. O aumento do endividamento, pela emissão de títulos da dívida interna, por exemplo, tem impacto direto na dívida mobiliária do Tesouro, aumentando a dívida do governo geral. Já a diminuição de ativos, pelo uso, por exemplo, de recursos da conta única do Tesouro junto ao Bacen, tende a aumentar indiretamente a dívida pública, pois o aumento de liquidez pela utilização desses recursos deve ser compensado pelo aumento no saldo das operações compromissadas. 
Em 2014, observa-se uma elevação mais expressiva no saldo das operações compromissadas, enquanto em 2015 o que se percebe é uma forte elevação da dívida mobiliária do Tesouro, acompanhada de uma pequena elevação das operações compromissadas ${ }^{1}$.

Pelo lado do ativo, a variação mais significativa se deu no valor das reservas internacionais. Diferente da variação ocorrida entre 2006 e 2013, contudo, nos dois últimos anos esse saldo variou mais em função da taxa de câmbio, dado que seu valor em dólar teve pouca variação. De fato, embora em percentual do PIB as reservas tenham passado de 16,4\% para 24,1\% do PIB entre 2013 e 2015, na moeda americana o saldo passou de US\$ 358,8 bilhões para US\$ 356,5 bilhões. A diferença, portanto, é explicada pela taxa de câmbio, que fechou 2013 próxima a 2,30 e em 2015 encerrou o ano a 3,90.

Em razão disso, a DBGG e Bacen se ampliou de 63,0\% para 77,3\% do PIB no período, um aumento de 14,4 p.p. A DLSP, como já mencionado, aumentou 5,6 p. p., tendo passado de $30,6 \%$ para $36,2 \%$ do PIB.

\subsection{Fatores condicionantes da evolução recente da dívida pública}

A análise da evolução recente da dívida mostrou as principais alterações ocorridas na composição e magnitude dos indicadores de endividamento aqui utilizados. Cabe, em complemento, explorar a dinâmica da dívida pública a partir de seus fatores condicionantes.

A análise dos fatores condicionantes é importante pois revela algumas das variáveis de fluxo que, embora não integrem o balanço patrimonial do setor público, ajudam a explicar mudanças em sua composição. O pagamento de juros nominais devidos, por exemplo, é um fator condicionante da variação da dívida potencialmente relacionado à emissão de títulos públicos, a qual teria reflexo na composição da dívida pelo aumento no saldo da dívida mobiliária do Tesouro.

Tal avaliação, ademais, nos permite extrair importantes considerações para análises prospectivas sobre a trajetória da dívida, objeto do capítulo 4.

As tabelas especiais contendo os dados sobre os fatores condicionantes da evolução da DBGG e da DLSP são disponibilizados eletronicamente pelo Bacen². Aqui optou-se por

\footnotetext{
${ }^{1}$ Um exame mais profundo das razões de ordem econômico-fiscal por trás das formas de financiamento do déficit fiscal observado em 2015 pode ser visto em Mendes (2016).

${ }^{2}$ Disponível em: <http://www.bcb.gov.br/pt-br/\#!/n/seriestemporais>.Acesso em: 17/6/2016.
} 
apresentá-los de forma gráfica, pois facilita a visualização da direção e magnitude do impacto que cada um desses fatores tem sobre a dívida. A figura 3 resume essas informações.

Figura 3 - Fatores condicionantes da evolução da dívida ${ }^{1}$

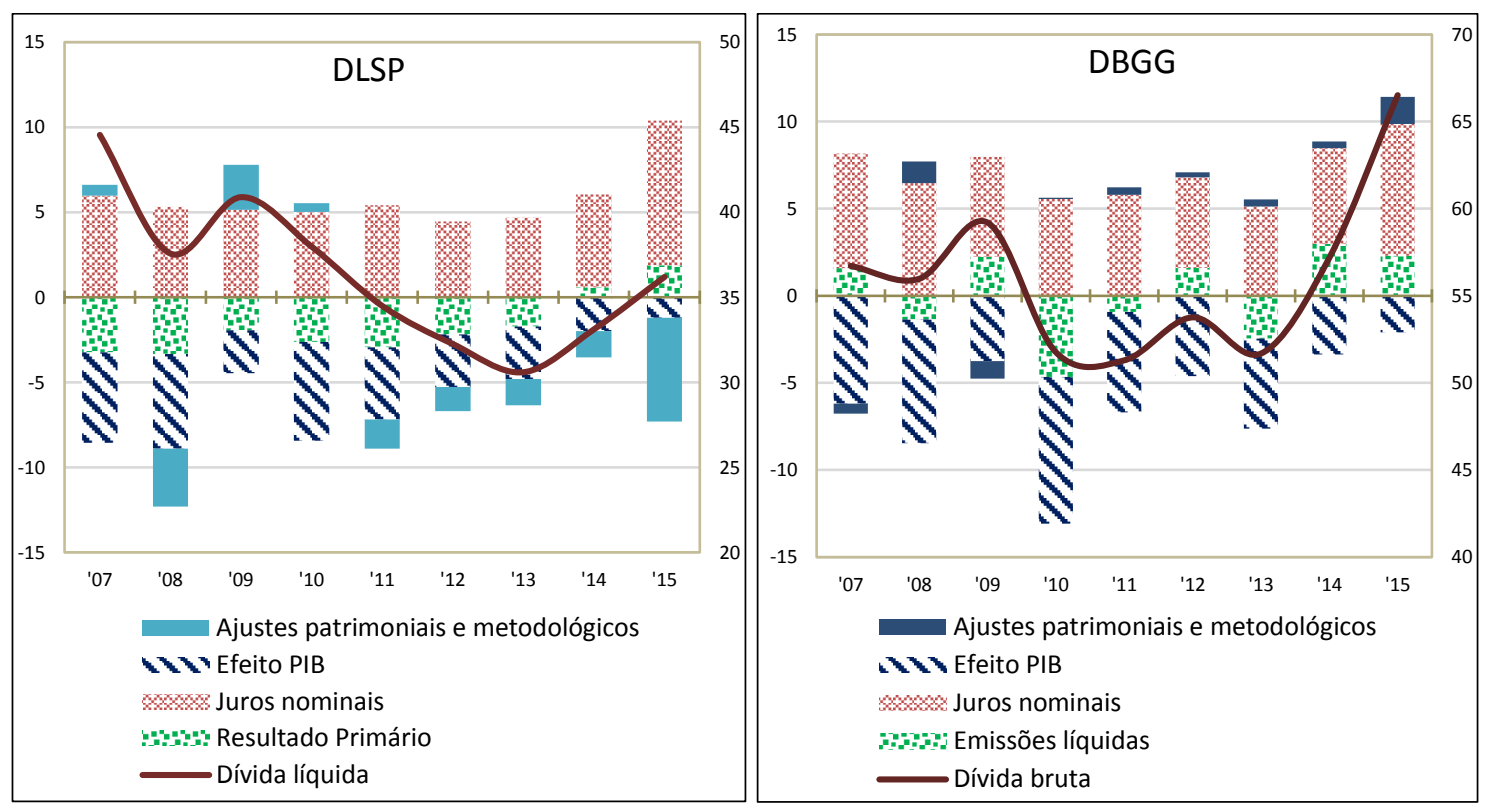

Fonte: Banco Central do Brasil. Elaboração Própria.

${ }^{1}$ Em ambos os gráficos, o eixo da direita se refere aos valores da dívida.

Como pode ser observado, ao longo dos últimos dez anos o principal fator condicionante da variação da dívida pública foram os juros nominais. Em 2014 e, especialmente, em 2015 esse impacto é ainda mais forte que nos anos anteriores. Conforme abordado no tópico anterior, o aumento decorre da elevação da inflação e da deterioração das contas públicas.

Outro aspecto importante é a diminuição do efeito do crescimento do PIB sobre os indicadores da dívida. Esse efeito, em realidade, é uma fatalidade algébrica. Como o valor dos indicadores fiscais é geralmente apresentado em percentual do PIB, aumentos do PIB nominal, tudo o mais constante, têm efeito redutor nos indicadores da dívida. $\mathrm{O}$ baixo crescimento real do PIB - ou retração, como em 2015 - faz com que essa variável tenha contribuição mais discreta sobre a variação da dívida.

A apresentação dos valores em relação ao PIB, no entanto, é a mais adequada, tendo em vista que a dívida pública é paga, em última instância, pela arrecadação de tributos e a capacidade de arrecadação, por sua vez, é dada pelo tamanho da riqueza nacional.

O resultado primário tem sido outro fator relevante para a dinâmica da dívida pública. Por aumentar as disponibilidades do governo, o impacto do resultado primário é evidenciado explicitamente apenas no gráfico da DLSP. Como nos dois últimos anos houve déficit primário, 
o resultado primário deixou de ter efeito redutor sobre a dívida líquida e passou a ser um dos fatores que geram variação positiva na dívida líquida.

No gráfico da DBGG, o resultado primário não é mostrado explicitamente. Isso porque, nesse caso, o impacto se dará via emissão (no caso de déficit primário) ou resgate de títulos (no caso de superávit primário), ampliando ou reduzindo a dívida mobiliária do Tesouro. A barra de emissões líquidas no gráfico da DBGG, portanto, incorporaria esse efeito.

Existe, contudo, a possibilidade de os resultados primários, em parte ou integralmente, não gerarem de imediato resgate ou emissão de dívida, mas apenas aumento ou redução de depósitos e aplicações do setor público. Nesses casos, no exercício em que ocorreram não provocariam redução da DBGG.

Os ajustes patrimoniais e metodológicos são fatores condicionantes da variação da dívida que não representam esforço fiscal propriamente dito. De forma geral, esses ajustes podem ser divididos em três grupos: i) ajustes cambiais; ii) ajuste de privatização; e iii) ajustes de reconhecimento de dívidas.

O primeiro grupo reflete as mudanças no valor em reais da dívida denominada em moeda estrangeira ou indexada à taxa de câmbio, causadas por variações cambiais. O segundo grupo reflete os recursos obtidos pelo governo com a venda de suas empresas ao setor privado. E o terceiro grupo evidencia novas dívidas criadas pelo reconhecimento de "esqueletos"3 ou em razão de reclassificação de contas que repercuta nas estatísticas fiscais.

Os ajustes tiveram efeito relevante sobre a evolução da dívida nos últimos anos, em especial sobre a DLSP. Para que se tenha uma leitura isolada dos impactos dos ajustes sobre a dívida, o gráfico a seguir mostra como teria sido a evolução da DLSP e da DBGG na ausência dos ajustes patrimoniais e metodológicos ${ }^{4}$. Os ajustes de privatização e reconhecimento de dívidas foram agrupados.

\footnotetext{
${ }^{3}$ Grosso modo, representam, no jargão orçamentário, passivos contingentes do ente federado, em geral originados de decisões judiciais e administrativas.

${ }^{4}$ Esse exercício hipotético tem inspiração em Garcia e Rigobon (2004).
} 
Figura 4 - Evolução hipotética da dívida sem ajustes patrimoniais e metodológicos
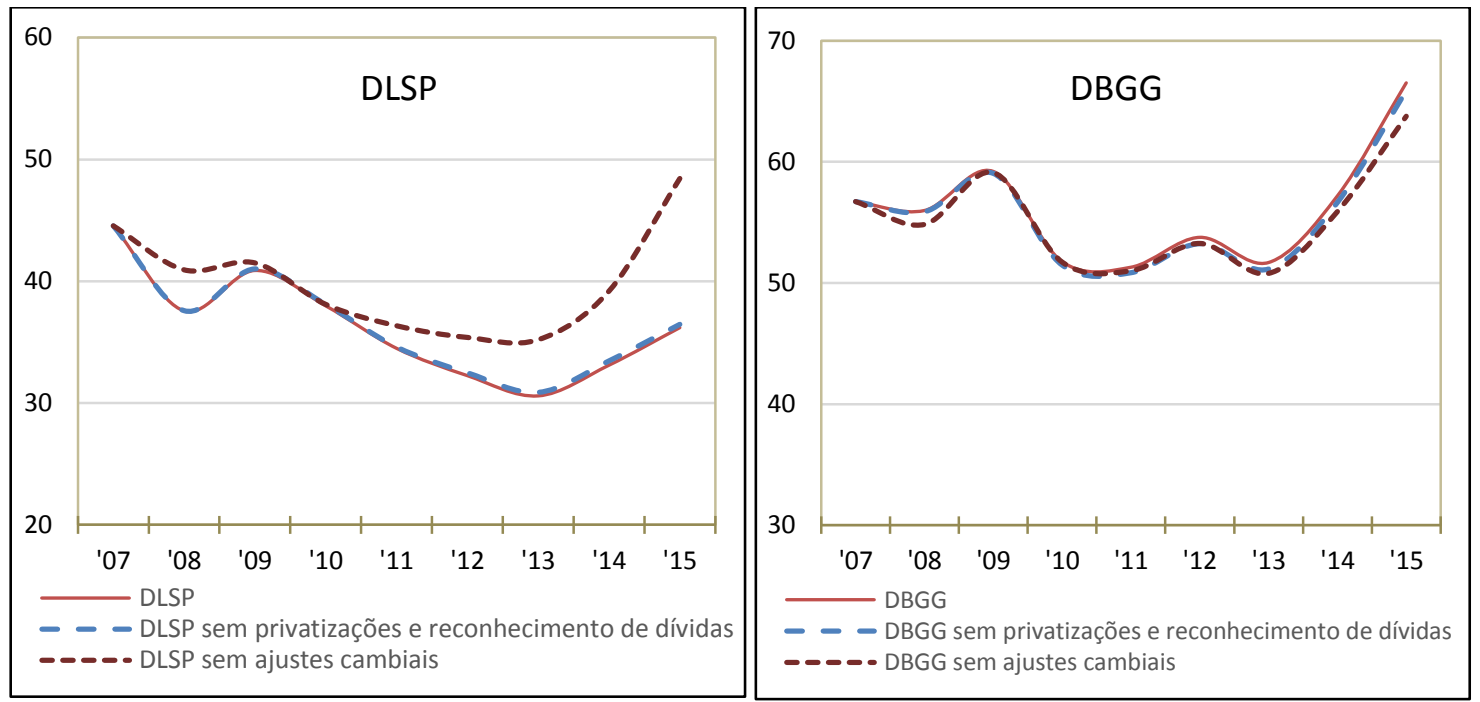

Fonte: Banco Central do Brasil. Elaboração Própria.

A partir desse simples exercício hipotético, torna-se fácil notar que, em relação à DLSP, a relevância dos ajustes patrimoniais e metodológicos decorre quase integralmente da variação cambial. O impacto do câmbio tem sido mais acentuado nos últimos anos e foi especialmente expressivo em 2015. Neste ano, o gráfico mostra que, não fosse a variação cambial, a DLSP estaria mais de 10 p.p. acima do nível efetivamente observado.

Isso decorre da desvalorização do real observada nos últimos anos, cujo efeito nas estatísticas da dívida se dá em grande medida sobre o valor em real das reservas internacionais, que compõem o ativo do setor público. Em linhas gerais, sempre que houver durante um período uma variação expressiva da taxa de câmbio sem correspondente variação no estoque de reservas, os ajustes cambiais tendem a ser significativos. Conforme comentado em tópico antecedente, isso foi precisamente o que ocorreu em 2015.

O fato de os ajustes cambiais decorrerem principalmente das variações no valor das reservas cambiais explica porque eles têm tido efeito limitado sobre a DBGG. Vale lembrar que a dívida externa se encontra hoje em patamar muito inferior ao historicamente observado, o que também ajuda a explicar a baixa relevância da variação cambial para a dinâmica da DBGG. O impacto dos demais ajustes patrimoniais e metodológicos sobre a trajetória da DBGG também tem sido pouco expressivo.

Esse exercício hipotético é relevante pois mostra, com base em dados passados, quais fatores de fato exercem influência sobre a dinâmica do endividamento. Isso deverá ser considerado nas análises propostas mais adiante, que traçam cenários prospectivos para o endividamento bruto do governo geral. 
Deve-se observar, contudo, que o exercício realizado neste capítulo não representa um contrafactual, mas apenas uma manipulação contábil. Isso porque não leva em consideração os efeitos que a retirada de uma variável teria nas demais variáveis que determinam a evolução da dívida. Na análise estocástica que será feita mais adiante essa questão será parcialmente tratada, pois permitirá que os choques sobre as variáveis sejam endogenamente determinados.

De todo o exposto neste capítulo, uma conclusão que inevitavelmente se extrai quando se analisa a dívida pública brasileira é que o exame em separado da evolução da dívida bruta e do ativo do governo geral tende a ser mais revelador do que a análise em si do comportamento da dívida líquida do setor público.

Sobre esse aspecto, Mendes (2016), em franca crítica ao uso da DLSP como indicador de sustentabilidade fiscal do país, observa que, nos últimos anos, a ênfase no emprego desse indicador como suporte à política fiscal adotada no período foi capaz de permitir uma política fiscal expansionista que não se refletia no aumento da dívida líquida, isso mesmo a despeito da criação de ativos com baixa perspectiva de realização. 


\section{A literatura sobre sustentabilidade fiscal}

O capítulo anterior tratou da evolução recente do endividamento público brasileiro. Em especial, foram examinadas algumas das mudanças ocorridas na composição e magnitude do ativo e passivo financeiros do setor público, bem como os principais fatores condicionantes da variação da dívida nos últimos anos. A análise retrospectiva é útil para que se possam traçar cenários prospectivos sobre o comportamento da dívida e, assim, avaliar sua sustentabilidade de médio e longo prazos.

O presente capítulo faz um compêndio das principais abordagens sobre o tema. Como a literatura teórica e empírica é extensa, buscou-se focar trabalhos seminais, a partir dos quais outros estudos foram feitos. De início, é descrita resumidamente a abordagem tradicional; em seguida, mencionam-se algumas análises que, em síntese, buscam testar a validade das hipóteses assumidas no enfoque tradicional; posteriormente, são trazidas abordagens que tentam lidar com o componente da incerteza; e, por fim, citam-se algumas análises aplicadas à dívida brasileira.

\subsection{A abordagem tradicional}

A abordagem tradicional sobre sustentabilidade da dívida pública se baseia nas implicações de médio e longo prazos de análises determinísticas a partir da equação que descreve a dinâmica da dívida. De posse da trajetória esperada do endividamento, é possível construir indicadores que forneçam uma medida da posição fiscal do governo. Essa abordagem segue os trabalhos seminais desenvolvidos por Buiter et al. (1985), Blanchard (1990) e Blanchard et al. (1991).

Presume-se em geral que os governos estão sujeitos a uma restrição orçamentária intertemporal (ROI), sendo esta não raro tomada como a própria definição de sustentabilidade. Em regra, a derivação da ROI se inicia com a descrição da dinâmica da dívida em determinado período 5 :

\footnotetext{
${ }^{5}$ Sem prejuízo para a análise, aqui ainda iremos considerar que a variação da dívida depende exclusivamente de variáveis fiscais, excluindo portanto, variações patrimoniais e expansão monetária.
} 


$$
D_{t}=\left(1+i_{t}\right) D_{t-1}-P_{t}
$$

Onde $t$ indexa o tempo, $D$ é o estoque da dívida; $i$ é a taxa nominal de juros cobrada sobre o estoque da dívida; e $P$ é o resultado primário (receitas menos despesas, excluindo as despesas e receitas com juros).

Para simplificar a notação, podemos definir:

$$
\lambda_{t}=\frac{i_{t}-\gamma_{t}}{1+\gamma_{t}}
$$

Em que $\gamma$ é o crescimento nominal do PIB, $Y$, tal que:

$$
Y_{N}=Y_{0} \prod_{t=1}^{N}\left(1+\gamma_{t}\right)
$$

As variáveis que compõem a ROI são normalmente apresentadas em proporção do PIB. Utilizando (2), a equação da evolução da dívida (1) se torna:

$$
d_{t}=\left(1+\lambda_{t}\right) d_{t-1}-p_{t}
$$

A equação diferencial tem solução:

$$
d_{N}=d_{0} \prod_{t=1}^{N}\left(1+\gamma_{t}\right)-\sum_{t=1}^{N}\left[\prod_{i=t+1}^{N}\left(1+\gamma_{i}\right)\right] p_{t}
$$

Sob a hipótese de que o crescimento nominal do PIB e a taxa nominal de juros são constantes (isto é, $i_{t}=i, \gamma_{t}=\gamma \mathrm{e}$, portanto, $\lambda_{t}=\lambda$ ), as equações assumem a forma abaixo:

$$
\begin{gathered}
d_{t}=(1+\lambda) d_{t-1}-p_{t} \\
d_{N}=d_{0}(1+\lambda)^{N}-\sum_{t=1}^{N}(1+\lambda)^{N-t} p_{t}
\end{gathered}
$$

Isolando $d_{0}$, obtem-se:

$$
\begin{gathered}
d_{0}=(1+\lambda)^{-N} d_{N}+\sum_{t=1}^{N}(1+\lambda)^{-t} p_{t} \\
\lambda=\frac{i-\gamma}{1+\gamma}
\end{gathered}
$$

Tirando o limite quando $n$ tende a infinito:

$$
D_{t}=\lim _{n \rightarrow \infty}(1+r)^{-n} D_{t+n}+\sum_{i=1}^{\infty}(1+r)^{-i} P_{t+i}
$$


A hipótese crucial por trás da ROI é que o primeiro termo do lado direito da equação, o valor presente da dívida no infinito, deve ser igual a zero:

$$
\lim _{n \rightarrow \infty}(1+r)^{-n} D_{t+n}=0
$$

Esta hipótese é denominada condição de transversalidade ou condição de não jogo de Ponzi. Com a condição de transversalidade, a ROI se torna:

$$
D_{t}=\sum_{i=1}^{\infty}(1+r)^{-i} P_{t+i}
$$

A ROI, dessa forma, diz que o valor presente da dívida deve ser igual ao valor presente dos resultados primários futuros. Em outras palavras, para que a restrição orçamentária valha, toda a dívida em algum momento deverá ser paga, o que deve ser satisfeito pelo governo por meio da geração de um ou mais superávits primários no futuro (considerando um valor presente da dívida positivo).

A condição de transversalidade, como visto, é também chamada de condição de não jogo de Ponzi. Um jogo (ou esquema) de Ponzi é um sistema no qual o retorno para investidores anteriores é pago por investimentos de novos investidores. No caso da dívida pública, o esquema equivaleria ao caso de o governo optar por pagar indefinidamente seus credores emitindo mais dívida.

As variáveis que compõem a ROI são normalmente apresentadas em proporção do PIB. Supõe-se, por simplificação, que o PIB, $Y$, cresça a uma taxa nominal constante $g$, tal que:

$$
Y_{t+n}=(1+g)^{n} Y_{t}
$$

Substituindo na ROI, tem-se:

$$
\begin{aligned}
& \frac{D_{t}}{Y_{t}}=\frac{(1+r)^{-n}(1+g)^{n} D_{t+n}}{Y_{t+n}}+\sum_{i=1}^{n} \frac{(1+r)^{-i}(1+g)^{i} P_{t+i}}{Y_{t+i}} \\
& d_{t}=\left(\frac{1+g}{1+r}\right)^{n} d_{t+n}+\sum_{i=1}^{n}\left(\frac{1+g}{1+r}\right)^{i} p_{t+i}
\end{aligned}
$$

Onde caracteres minúsculos se referem a variáveis apresentadas em razão do PIB. Agora deve-se considerar uma nova variável, que é a taxa de crescimento nominal do PIB. Tirando limites, tal como feito anteriormente:

$$
d_{t}=\lim _{n \rightarrow \infty}\left(\frac{1+g}{1+r}\right)^{n} d_{t+n}+\sum_{i=1}^{\infty}\left(\frac{1+g}{1+r}\right)^{i} p_{t+i}
$$

A nova versão da condição de transversalidade será:

$$
\lim _{n \rightarrow \infty}\left(\frac{1+g}{1+r}\right)^{n} d_{t+n}=0
$$


A nova condição é equivalente à anterior. No entanto, para variáveis em proporção do PIB a interpretação é diferente: no limite a razão dívida/PIB deve crescer a uma taxa menor do que $\left(\frac{1+r}{1+g}\right)$. Para $r>g$, isso permite trajetórias de crescimento exponencial da razão dívida/PIB. Para $r=g$, a dívida/PIB deve ser constante e, para $r<g$, a dívida/PIB deve convergir exponencialmente para zero.

Essa interpretação é intuitiva: se o estoque da dívida cresce a uma taxa superior ao crescimento do PIB (ou seja, $r>g$ ), a razão dívida/PIB tende a crescer com o tempo. Em sentido contrário, se o estoque da dívida cresce a uma taxa inferior ao crescimento do PIB (ou seja, $r<g$ ), a razão dívida/PIB tende a diminuir com o tempo.

Estabelecida a nova condição de transversalidade, a ROI então será:

$$
d_{t}=\sum_{i=1}^{\infty}\left(\frac{1+g}{1+r}\right)^{i} p_{t+i}
$$

Em resumo, a abordagem tradicional prevê que, se assumirmos que o governo é comprometido com o pagamento da dívida, uma dívida que satisfaça a restrição orçamentária intertemporal deve ser considerada sustentável. Ou seja, uma dívida sustentável deve ser igual ao valor presente descontado dos superávits primários futuros.

A partir desse arcabouço, podem ser construídos indicadores de sustentabilidade de construção (e intuição) relativamente fácil. Em geral, a medida de interesse é o ajuste fiscal requerido para que se atinja, em determinado horizonte de tempo, o nível de endividamento almejado. A derivação desse indicador é feita a partir da equação (2) ${ }^{6}$ :

$$
d_{t}=\left(\frac{1+g}{1+r}\right)^{n} d_{t+n}+\sum_{i=1}^{n}\left(\frac{1+g}{1+r}\right)^{i} p_{t+i}
$$

Isolando $d_{t+n}$, tem-se:

$$
d_{t+n}=\left(\frac{1+\mathrm{r}}{1+\mathrm{g}}\right)^{n} d_{t}-\sum_{i=1}^{n}\left(\frac{1+\mathrm{r}}{1+g}\right)^{n-i} p_{t+i}
$$

Definindo um intervalo de tempo específico $[\mathrm{t}, \mathrm{T}]$ e uma meta de dívida a ser alcançada ao final do período, tem-se a condição relativa ao ajuste fiscal - anual e constante - necessário para se atingir a meta especificada, que aqui chamaremos de hiato fiscal de horizonte finito $\left(\mathrm{HF}^{\text {fin }}\right)$ :

\footnotetext{
${ }^{6}$ Há mais de uma forma de derivar esse indicador, embora todas semelhantes entre si. Aqui seguimos a forma adotada em Sarvi (2009).
} 


$$
d_{T}=\left(\frac{1+\mathrm{r}}{1+\mathrm{g}}\right)^{T-t} d_{t}-\sum_{i=1}^{T-t}\left(\frac{1+\mathrm{r}}{1+g}\right)^{T-t-i}\left(p_{t+i}+\mathrm{HF}^{\text {fin }}\right)
$$

Isolando $\mathrm{HF}^{\text {fin }}$, tem-se:

$$
\mathrm{HF}^{f i n}=\frac{\left(d_{t}-\left(\frac{1+\mathrm{g}}{1+\mathrm{r}}\right)^{T-t} d_{T}-\sum_{i=1}^{T-t}\left(\frac{1+\mathrm{g}}{1+r}\right)^{i} p_{t+i}\right)(r-g)}{\left(1-\left(\frac{1+g}{1+r}\right)^{T-t}\right)(1+g)}
$$

O hiato fiscal de horizonte finito, portanto, evidencia qual o ajuste fiscal necessário, em proporção do PIB, para que a relação dívida/PIB alcance a meta almejada em determinado horizonte de tempo. Muitas vezes a meta almejada é simplesmente estabilizar a dívida no nível em que se encontrava no momento inicial (caso em que teríamos $d_{T}=d_{t}$ ).

O hiato fiscal pode ser calculado para horizonte de tempo infinito. Nesse caso, a equação da dívida e o hiato fiscal se tornam, respectivamente:

$$
\begin{aligned}
d_{t} & =\sum_{i=1}^{\infty}\left(\frac{1+g}{1+r}\right)^{i}\left(p_{t+i}+H F^{\text {inf }}\right) \\
\mathrm{HF}^{\text {inf }} & =\frac{\left(d_{T}-\sum_{i=1}^{\infty}\left(\frac{1+\mathrm{g}}{1+r}\right)^{i} p_{t+i}\right)(r-g)}{(1+g)}
\end{aligned}
$$

Outra medida possível é o ajuste fiscal imediato necessário para satisfazer a restrição orçamentária intertemporal. Ou seja, simplesmente a diferença entre o fluxo futuro esperado de resultados primários e o nível atual da dívida. No caso de horizonte de tempo infinito, teríamos:

$$
H F=\sum_{i=1}^{\infty}\left(\frac{1+g}{1+r}\right)^{i} p_{t+i}-b_{t}
$$

Esses indicadores admitem que se construam diferentes trajetórias para o resultado primário. Alternativamente, o interesse pode estar no resultado primário constante que estabilize a relação dívida/PIB, conforme proposto originalmente por Buiter et al. (1985). Assumindo $r>g$, substituindo $p_{i}=p^{*}$ na ROI e resolvendo para $p$, tem-se:

$$
p^{*}=\frac{(r-g) d_{t}}{1+g}
$$

Se $p_{i}>p^{*}$, a dívida cairá em proporção do PIB deverá cair e o contrário se $p_{i}<p^{*}$. A única condição de estabilidade da dívida é se $p_{i}=p^{*}$.

Indicadores desse tipo têm larga utilização pelos governos nacionais, FMI ou no âmbito das chamadas instituições fiscais independentes. O Congressional Budget Office americano (CBO) e o Parliamentary Budget Officer do Canadá (PBO) utilizam esses 
indicadores para analisar o 25, 50 e 75 anos, colocando como meta para o fim do período o valor inicial da razão dívida/PIB. A Comissão Europeia também tem um indicador equivalente para os países membros da União Europeia. Nesse caso, o último ano das projeções é 2060 e a meta da dívida é de $60 \%$ do PIB.

As abordagens derivadas da restrição orçamentária intertemporal do governo, embora amplamente utilizadas, não são imunes a críticas. Giammarioli et al. (2007) lembra que esse tipo de análise falha em captar as interações entre as finanças públicas e agregados macroeconômicos. Isso porque os indicadores de sustentabilidade se sustentam em projeções de receitas e despesas primárias, crescimento econômico e taxas de juros, cuja determinação se dá de forma exógena ao modelo. Os efeitos de trajetórias insustentáveis da dívida sobre o crescimento do PIB ou sobre a taxa de juros são negligenciados. Dado que níveis de endividamento mais elevados podem exercer pressão positiva sobre a taxa de juros e reduzir o crescimento, o que, por sua vez, contribui para a dinâmica ascendente da dívida, indicadores de sustentabilidade podem ser enganosos, em particular pelo fato de que podem subestimar os riscos fiscais associados a determinada trajetória fiscal.

Barnhill e Kopits (2003) argumenta, em acréscimo, que, embora essa abordagem forneça uma indicação de vulnerabilidade do setor público, ela não considera explicitamente o elevado grau de incerteza inerente às projeções das variáveis do modelo, o que reduz a utilidade das análises para avaliar sustentabilidade. Essa é uma limitação ainda maior no caso de economias emergentes, as quais podem ser particularmente vulneráveis a mudanças repentinas no humor do mercado em relação à volatilidade econômica e ao ambiente financeiro.

Para mitigar esse problema, muitas análises têm incluído choques arbitrários (ver, por exemplo, Giuliano e Sandleris (2010)) ou testes de sensibilidade para as variáveis do modelo (ver, por exemplo, Comissão Europeia (2016)). Esses avanços, embora úteis, têm efeito limitado, pois não consideram interações entre as variáveis.

D'Erasmo et al. (2015), além de citar o problema relacionado à ausência de incerteza na abordagem convencional, chama atenção para o fato de que esse arcabouço apenas define uma trajetória de resultados primários para dado nível da dívida (ou vice-versa) ou o limite mínimo para a dinâmica de curto prazo do resultado primário. No entanto, para um determinado nível de dívida em qualquer período de tempo, há múltiplos caminhos do resultado primário que satisfazem a ROI.

Sarvi (2009) alerta para o fato de que as implicações em termos de política fiscal dos indicadores construídos para identificar hiatos fiscais não são diretas, tampouco livres de dilemas. O autor cita a conhecida teoria desenvolvida por Barro (1979) sobre suavização da 
tributação, segundo a qual a tributação deveria ser mantida constante ao longo do tempo para minimizar distorções tributárias intergeracionais. Dessa forma, variações temporárias na despesa poderiam ser absorvidas pelo orçamento, enquanto variações permanentes na despesa demandariam mudanças permanentes na tributação. Tendo em vista que um dos principais desafios fiscais de grande parte dos países se origina da transição demográfica e que esta tem efeito permanente sobre a despesa pública, a recomendação seria um aumento permanente da tributação, o que, no entanto, poderia causar problemas de equidade geracional.

\subsection{Testes econométricos}

A abordagem tradicional lançou as bases para os estudos sobre sustentabilidade fiscal que se desenvolveram em seguida. Por prover informações diretas e de fácil comunicação, ainda hoje é amplamente utilizada, muitas vezes como uma aproximação inicial ao problema, a partir da qual outras abordagens podem ser realizadas.

Nesse sentido, parte considerável da literatura relacionada ao tema se ocupa da análise de dados fiscais em retrospectiva para saber se a dívida do governo seguiu de fato um processo estacionário ou para identificar possíveis cointegrações entre receitas e gastos governamentais.

Essa linha de pesquisa é inaugurada por Hamilton e Flavin (1986), que deriva um teste estatístico para determinar se a condição de transversalidade ou, de forma equivalente, a restrição orçamentária intertemporal é observada empiricamente. Os autores concluem que a estacionariedade do superávit primário e do estoque da dívida pública garantem que a política fiscal americana implementada durante entre 1960 a 1984 era sustentável no longo prazo, uma vez que o governo respeitou sua restrição orçamentária intertemporal.

No entanto, não há consenso sobre a sustentabilidade da política fiscal americana no período. Wilcox (1989), com base no mesmo conjunto de dados utilizado por Hamilton e Flavin (1986), mostra que, se a hipótese de taxa de juros constante for relaxada e forem consideradas violações estocásticas à restrição orçamentária, então deve-se rejeitar a hipótese de que a ROI é respeitada.

Trehan e Walsh (1988), por seu turno, mostra que a validade da restrição orçamentária intertemporal é equivalente à condição de que os gastos do governo, inclusive com juros, as receitas tributárias e a senhoriagem sejam cointegrados. Essa condição ainda requer que o 
déficit público, incluindo juros, seja estacionário. Os autores concluem que as condições acima foram satisfeitas pela economia americana no longo período entre 1890 e 1986.

Hakkio e Rush (1991), em linha com a condição estabelecida por Trehan e Walsh (1988), e utilizando dados da economia americana para o período entre 1950 e 1988, não rejeita a hipótese de cointegração entre despesa e arrecadação fiscal. Contudo, para o período entre 1964 e 1988, a maioria dos testes sugere que as séries não cointegram.

Trehan e Walsh (1991), em acréscimo, mostra que, se a taxa real de juros esperada não for constante, mas positiva, e o déficit público (incluindo juros) for estacionário, a restrição orçamentária intertemporal é respeitada.

Afonso (2005), na esteira dos trabalhos realizados com foco na economia americana, analisa a sustentabilidade fiscal de quinze países da União Europeia, por meio de um teste de cointegração entre receitas e despesas do governo. Os resultados revelam que, com poucas exceções, os países da UE apresentaram taxa de crescimento para as despesas maior do que a taxa de crescimento das receitas e estavam propensos a enfrentar problemas de sustentabilidade, ainda que as dívidas em percentual do PIB mostrassem sinais de estabilização no final da década de 1990. O autor alerta que esse problema pode se tornar mais crítico se considerado o envelhecimento das populações desses países e o consequente aumento das despesas públicas com previdência.

Bohn (1998) introduz uma nova abordagem para a sustentabilidade fiscal a partir de testes econométricos. Em particular, o objeto de análise é a relação histórica entre o resultado primário e mudanças na relação dívida/PIB na economia americana, estabelecendo o que ficou conhecido como função de reação fiscal (FRF). Uma resposta positiva do resultado primário a um aumento da dívida, nesse contexto, mostraria que a política fiscal responde de forma a compensar esse aumento, por meio de redução das despesas ou elevação da arrecadação.

O autor mostra que uma FRF estritamente positiva, ou pelo menos linear, do resultado primário é suficiente para garantir a sustentabilidade da dívida. Essa definição de sustentabilidade seria superior àquela fornecida pela abordagem tradicional e, diferentemente, não dependeria de nenhuma hipótese acerca do comportamento das taxas de juros.

Grosso modo, a reação fiscal prevista por Bohn (1998) seria determinada pela seguinte regressão:

$p_{t}=\lambda d_{t}+\mu_{t}$

Onde $\mu_{t}$ é um conjunto de outros fatores que impactam o resultado primário.

Bohn (1998) estima a FRF para dados dos Estados Unidos no período entre 1916 e 1995 e encontra um coeficiente $\lambda$ estatisticamente significante e maior que zero, o que fornece 
forte evidência de que o governo americano havia historicamente reagido a aumentos na dívida por meio de superávits primários maiores (ou déficits menores). Logo, a política fiscal americana teria sido sustentável no período, mesmo a despeito dos frequentes déficits primários.

FMI (2003) estima a FRF para uma amostra de países industrializados e em desenvolvimento. Os resultados mostram que a condição de sustentabilidade baseada no modelo proposto por Bohn (1998) é válida para os países industrializados e para países em desenvolvimento, embora neste último grupo apenas nas economias com nível de endividamento mais baixo. Com efeito, em relação aos países em desenvolvimento, a resposta do resultado primário tende a enfraquecer à medida que cresce a relação dívida/PIB, e cessa quando a dívida excede $50 \%$ do PIB. Isso sugere que, em média, a condução da política fiscal nesse grupo de países não é consistente com a garantia da sustentabilidade a partir do patamar de $50 \%$ do PIB.

Bohn (2005) propõe algumas alterações ao modelo original e o aplica a um conjunto de dados da economia americana significativamente maior, 1792 a 2003. Mais uma vez, o autor encontra forte evidência de sustentabilidade da política fiscal nos EUA, representada por respostas positivas do resultado primário em razão de variações na dívida no período.

Sarvi (2009) aponta algumas limitações do modelo proposto por Bohn. Uma delas está relacionada ao fato de que testes econométricos fornecem informação apenas retrospectiva, ou seja, sobre a sustentabilidade fiscal de políticas passadas, enquanto muitas vezes o interesse está voltado para a sustentabilidade da política fiscal corrente quando projetada para o futuro. Em adição, a opção de aplicar testes econométricos em dados projetados envolveria o risco de que esses dados já incorporassem as relações esperadas com base na análise retrospectiva. $\mathrm{O}$ autor acrescenta que, diferente dos indicadores elaborados a partir da abordagem convencional, o modelo de Bohn não fornece uma medida quantitativa da sustentabilidade, se limitando a aceitar ou rejeitar tal hipótese.

A transição demográfica, no caso dos países em desenvolvimento, é um fenômeno relativamente novo e sugere ainda maior cautela ao se interpretarem os resultados de testes econométricos baseados em dados passados. Com efeito, passivos contingentes relacionados à previdência social são parte do desequilíbrio fiscal de um país e devem ser entendidos como uma necessidade adicional de financiamento ainda não incorporada às estatísticas fiscais, levando, ceteris paribus, a maiores problemas de sustentabilidade no futuro. 


\subsection{Abordagens baseadas em incerteza}

Como visto, o principal objetivo das análises econométricas, em resumo, é testar a hipótese de que a condição de solvência dada pela restrição orçamentária do governo foi observada em determinado país com base na série histórica de dados fiscais. Tais testes, no entanto, não são capazes de unir as fontes de incerteza macroeconômica à dinâmica da dívida pública e, dessa forma, fornecer adequadamente medidas de sustentabilidade da dívida pública para o médio e longo prazos.

Em resposta, alguns trabalhos relativamente mais recentes têm buscado lidar justamente com a questão da incerteza inerente ao comportamento de variáveis macroeconômicas e negligenciada na abordagem tradicional.

Uma das principais contribuições nesse sentido é encontrada em Barnhill and Kopits (2003). Os autores lembram que os indicadores de sustentabilidade convencionais relegam ao usuário da informação a tarefa de verificar a margem de erro em torno dos cenários-base dos indicadores. Não surpreende, portanto, que analistas de mercado tendem a adotar uma postura bem mais cautelosa, ao assumir projeções mais conservadoras para os parâmetros macroeconômicos. Em contraste, o governo tem o interesse particular em mostrar uma imagem mais animadora da posição fiscal, assumindo hipóteses mais otimistas.

Barnhill and Kopits (2003) propõe então uma avaliação da sustentabilidade fiscal baseada em cálculos de cenários, com o intuito de dar um tratamento mais realista e explícito aos riscos enfrentados pelo setor público. Especificamente, eles propõem a utilização da ferramenta de gerenciamento de risco Value-at-Risk (VaR), geralmente empregada no âmbito de instituições financeiras. Essa abordagem permite simular uma distribuição de possíveis condições fiscais futuras e avalia a probabilidade de resultados adversos, dada essa distribuição e um determinado nível de confiança.

Os autores modelam o que seria o valor líquido do setor público como uma função de variáveis de risco subjacentes, como crescimento do PIB, taxa de juros, taxa de câmbio, preço de commodities e inflação doméstica. Assumindo que essas variáveis de risco seguem processos estocásticos conhecidos (embora diferentes entre si) e determinando a variância e covariância subjacentes às variáveis, é possível simular valores para as variáveis. A partir desses valores, estimam-se distribuições para os ativos e passivos do setor público e, então, calculam-se medidas relevantes de risco, como a probabilidade de que determinado governo seja incapaz de pagar sua dívida. 
Barnhill and Kopits (2004) aplica essa metodologia para avaliar a sustentabilidade fiscal do Equador, concluindo que em 2000 o país se encontrava em situação de considerável vulnerabilidade fiscal. $\mathrm{Na}$ ausência de risco, o valor líquido do setor público no Equador não sugeria, em princípio, um problema de solvência no país. No entanto, ajustado pelo risco, a estimativa do valor líquido variava consideravelmente, indicando que algumas fontes de risco para as finanças públicas do país, como por exemplo o preço do petróleo, causam uma forte volatilidade no valor líquido do setor público. A probabilidade de insolvência - ou seja, estimar um valor líquido do setor público negativo - havia sido de $35 \%$.

Uma das qualidades da abordagem proposta por Barnhill and Kopits é o fato de levar em consideração tanto variáveis fiscais de fluxo, a exemplo das receitas e despesas, como também variações no valor de ativos e passivos do balanço do setor público que podem afetar a dinâmica do endividamento público. Por ser bastante compreensiva, contudo, a necessidade de um grande número de informações sobre as variáveis de risco do setor público, nem sempre de fácil disponibilidade, é uma das limitações do modelo.

Outra limitação dessa abordagem se deve ao fato de que descrever variáveis estocásticas no longo prazo pode não ser de grande valia para a análise, dado que o grau de incerteza decorrente da interação entre elas pode gerar cenários muito abrangentes. Apenas como ilustração, seria o caso de se estimar que a dívida de determinado país se situaria, em vinte anos, entre $10 \%$ e $200 \%$ do PIB com nível de confiança de $90 \%$. Embora este pudesse ser um resultado consistente, ele não permitiria extrair conclusões relevantes sobre a sustentabilidade da política fiscal do país.

Recentemente novas abordagens têm sido desenvolvidas com a intenção de estimar um teto para a dívida pública, o que teria a utilidade de indicar o montante adicional de endividamento que determinado país seria capaz de suportar.

Ostry et al. (2010) introduz uma abordagem para estimar o espaço fiscal do governo a partir de sua postura fiscal passada. O espaço fiscal, nesse contexto, seria a diferença entre o nível presente da dívida pública e o limite de endividamento derivado do histórico de ajustamento da política fiscal. A estimativa do limite da dívida é baseada da função de reação fiscal, conforme proposta por Bohn (1998).

Os autores observam que, enquanto a política fiscal tende a responder positivamente ao aumento da dívida, esse esforço tende a enfraquecer para níveis de endividamento mais elevados, dado que a partir de certo ponto aumentos de tributos e cortes de despesas tendem a se tornar cada vez menos plausíveis do ponto de vista político. 
Para levar em consideração a incerteza, Ostry et al. (2010) reporta as probabilidades de que determinado país tenha algum espaço fiscal remanescente. No caso da Grécia, por exemplo, o resultado empírico mostrou que essa probabilidade era de apenas $6,3 \%$ na época do estudo.

Uma das vantagens dessa abordagem é o fato de que a interação entre a taxa de juros e o nível de endividamento é explicitamente modelada. Além disso, os conceitos de limite da dívida e espaço fiscal são relativamente intuitivos e fáceis de comunicar. Por outro lado, assim como em Barnhill and Kopits (2003), a abordagem requer uma quantidade relativamente grande de dados para determinar a função de reação fiscal, o que pode ser uma limitação a depender do país que será estudado.

Di Giovanni e Gardner (2008) propõe uma metodologia relativamente simples para a obtenção de intervalos de confiança em torno de um cenário central determinístico para a dívida pública. A partir do histórico de choques nas variáveis estocásticas que integram a dinâmica da dívida, os autores desenham choques aleatórios para o período preditivo, de posse dos quais é possível calcular, por meio de simulações de Monte Carlo, diferentes trajetórias para a dívida pública no médio prazo e, dessa forma, construir os intervalos de confiança em torno do cenário-base.

Di Giovanni e Gardner (2008) aplica a metodologia para o Líbano no período de 2008 a 2012 e conclui que o ajuste fiscal então proposto no país, mesmo considerando a incerteza em torno de algumas variáveis macroeconômicas, provavelmente colocaria a dívida pública em trajetória decrescente.

A abordagem de Di Giovanni e Gardner (2008) é utilizada por Beynet e Paviot (2012) para analisar a sustentabilidade fiscal da Hungria no período de 2012 a 2016. Essa metodologia também é utilizada por Berti (2013) para os países da União Europeia, o qual serviu de base para a Comissão Europeia em seu Relatório de Sustentabilidade Fiscal relativo a 2015.

\subsection{Análises aplicadas ao caso brasileiro}

Há uma vasta literatura sobre a sustentabilidade da dívida pública brasileira, tendo boa parte se desenvolvido no período pós-estabilização e, em especial, após o advento da LRF. 
Seguindo a abordagem determinística tradicional e em linha com o arcabouço analítico desenvolvido pelo FMI até o início dos anos 2000, Goldfajn e Guardia (2003) constrói um cenário prospectivo determinístico para a dívida líquida brasileira. Os autores calculam, em acréscimo, o superávit primário requerido para estabilizar a relação dívida/PIB considerando diferentes combinações de taxas de crescimento do PIB e taxas de juros. As projeções concluíram pela sustentabilidade da dívida pública brasileira, desde que mantido o desempenho fiscal alcançado a partir de 1998 e intensificado com a edição da LRF.

A maior parte dos estudos realizados sobre a sustentabilidade da dívida pública brasileira, no entanto, busca analisar o tema por meio da aplicação dos testes econométricos desenvolvidos originalmente para a dívida americana por Hamilton e Flavin (1986), Wilcox (1989), Hakkio e Rush (1991) e Bohn (1998, 2005), divergindo eventualmente quanto ao conjunto de dados examinados e ao período.

Rocha (1997) analisa a consistência da trajetória dos gastos, receitas e dívida do governo federal brasileiro com a restrição orçamentária intertemporal para o período de 1980 a 1993 por meio de dois testes. O primeiro examina o processo gerador da dívida interna e o segundo a relação entre gastos e receitas do governo. A evidência empírica sugere a existência de equilíbrio orçamentário intertemporal. Contudo, os resultados indicam que a senhoriagem no período foi uma fonte importante de receita para o governo. Desconsiderando a senhoriagem como receita, a restrição orçamentária teria deixado de ser observada.

Issler e Lima (1997) investiga a sustentabilidade da dívida brasileira usando testes de raiz unitária e de cointegração, além de calcular funções de resposta a impulso baseadas em modelos vetoriais de correção de erros. A análise cobre o período de 1947 a 1992. Assim como Rocha (2007), eles mostram que a dívida é sustentável somente se a senhoriagem estiver incluída como receita do governo e que as despesas do governo são exógenas. Além disso, os testes de resposta a impulso mostram que desequilíbrios fiscais tendem a ser eliminados por meio de aumento de impostos, o que seria consistente com a equivalência ricardiana.

A abordagem de Issler e Lima (2007) foi seguida por Silva e Gamboa (2011) para analisar o período entre 1986 e 2007. Os resultados confirmam a existência de cointegração entre gasto e arrecadação na dinâmica fiscal brasileira, mas apenas quando incluída a senhoriagem como fonte adicional de receita.

Luporini (2000), utilizando testes de raiz unitária e de não estacionariedade, também conclui pela sustentabilidade a dívida brasileira, neste caso para o período de 1966 a 1996. Para o subperíodo de 1981 a 1996, contudo, os resultados indicaram que a política fiscal se tornou 
insustentável e o refinanciamento do governo só foi possível com a ajuda do Banco Central, por meio de emissão de títulos ${ }^{7}$ e acordos de recompra de títulos.

Luporini (2001), por sua vez, aplica a metodologia proposta por Bohn (1998) ao analisar a sustentabilidade da dívida pública no período entre 1966 e 2000. Os resultados mostram que o resultado primário não respondeu sistematicamente a mudança na dívida, indicando que a política fiscal não poderia ser considerada sustentável durante o período analisado. Em adição, a relação dívida/PIB não apresentou tendência de reversão à média, mesmo quando variações cíclicas no nível de renda e de gastos governamentais foram levadas em consideração, o que também sugere um padrão não sustentável para a política fiscal brasileira naquele período.

Bicalho (2005) e De Mello (2005) também estimam funções de reação fiscal para a política fiscal brasileira com base em Bohn (1998), mas utilizando dados do período pósestabilização (1997-2004, no primeiro caso, e 1995-2004, no segundo). Em contraste com os resultados obtidos por Luporini (2001), esses dois trabalhos mostram que o governo tende a reagir a mudanças na dívida com aumento no resultado primário e concluem pela sustentabilidade da dívida pública brasileira no período. Mello (2005), em linha com Issler e Lima (1997), enfatiza que a política fiscal brasileira segue um regime de "spend-and-tax”, isto é, aumentos de gastos, numa perspectiva de longo prazo, tendem a ser compensados com aumentos de receita.

Simonassi (2007) aplica a metodologia proposta por Bohn (2005) para estimar, a partir de dados de 1991 a 2006, uma função de reação para o Brasil, permitindo múltiplas quebras estruturais endógenas de acordo com a proposta de Bai e Perron (1998). Os resultados indicam que a política fiscal foi sustentável ao longo do período analisado. A respostas fiscais a aumentos da dívida se tornam significativas a partir de maio de 1995, quando se observa uma mudança estrutural na política fiscal brasileira. Com efeito, esse período é marcado pela edição de duas leis de renegociação de dívidas de entes subnacionais e por diversas restrições ao endividamento dessas esferas de governo. Diferente dos estudos que analisaram períodos préestabilização, o autor também mostra que a melhora do resultado fiscal do governo está associada à relativa irrelevância do uso da senhoriagem como fonte de financiamento.

Mendonça et al. (2009) estima a função de reação fiscal do setor público consolidado brasileiro de 1995 a 2007 por meio de um modelo Markov-switching. Esse modelo permite lidar com a incerteza referente às possíveis mudanças de regime ocorridas no período. Os

\footnotetext{
${ }^{7}$ Vale lembrar que a emissão de títulos pelo Bacen era possível até a edição da LRF.
} 
resultados mostram que até 2000 havia uma evidente reação do superávit primário a variações da dívida líquida, enquanto que, a partir de 2001, a política fiscal caracteriza-se por uma baixa (ou mesmo nula) reação do superávit primário a variações na DLSP. Os autores observam, ainda, que em ambos os períodos o superávit primário pareceu responder positivamente a variações no produto e que em nenhum dos dois períodos o governo pareceu ter utilizado explicitamente a política fiscal como instrumento de controle da inflação.

Luporini (2015), além de estimar uma função de reação fiscal para o Brasil, investiga como ela evoluiu ao longo do período analisado (1991 a 2011) para, assim, identificar possíveis mudanças no comportamento fiscal do governo. Os resultados indicam que a política fiscal no período como um todo foi sustentável, mas que a função de reação se tornou menos sensível a aumentos da relação dívida/PIB após 2000 e assumiu uma tendência declinante após 2006.

Chicoli (2016), por sua vez, estima uma função de reação fiscal que considera os efeitos das operações de contabilidade criativa e os empréstimos do governo federal para bancos públicos, principalmente BNDES. Utiliza, para isso, diversos conceitos de superávit primário (oficial; oficial excluindo as receitas de contabilidade criativa; e permanente) e de endividamento (dívidas líquida, bruta e bruta excluídas reservas internacionais), para o período de 2003 a 2014. Em nenhum dos casos analisados a hipótese de sustentabilidade foi satisfeita, sugerindo a necessidade de se alterar a política fiscal do país. Por meio de testes de quebra estrutural, à feição de Bai e Perron (1998), verificou-se que a alteração no padrão da política fiscal pós-crise de 2008 foi um dos principais responsáveis pelo resultado de não sustentabilidade.

Dentro da classe mais recente de estudos que buscam lidar com a incerteza inerente ao comportamento da economia, Garcia e Rigobon (2004) propõe uma abordagem de gerenciamento de risco com base em vetores autorregressivos (VAR) para estimar o padrão de correlação entre as variáveis macroeconômicas e o utiliza para realizar simulações de Monte Carlo para a dívida pública. Essas simulações permitem que se calculem "probabilidades de risco", como a probabilidade de que a relação dívida/PIB exceda determinado patamar considerado arriscado do ponto de vista de sua sustentabilidade.

Os autores partem do reconhecimento de que as variáveis que entram a equação da dívida são estocásticas e talvez correlacionados. Além disso, consideram a possibilidade de que existem outras variáveis externas (como câmbio e inflação) que poderiam gerar comovimento nas variáveis da equação. Em termos analíticos, os autores pressupõem que:

$$
\begin{gathered}
d_{t}=\left(1+r_{t}-g_{t}\right) d_{t-1}+f_{t}+\varepsilon_{t} \\
\left\{\widetilde{r_{t}}, \widetilde{g_{t}}, \widetilde{p_{t}}, \widetilde{\varepsilon_{t}}, \widetilde{s_{t}}, \widetilde{\pi_{t}}\right\} \sim N\left(\vec{\mu}_{t}, \Sigma_{t}\right)
\end{gathered}
$$


Em que $\widetilde{r_{t}}, \widetilde{g_{t}}, \widetilde{p_{t}}, \widetilde{\varepsilon_{t}}, \widetilde{s_{t}}, \widetilde{\pi_{t}}$ são as versões estocásticas da taxa real de juros, do crescimento do PIB, do déficit primário, choques na dívida (esqueletos e privatizações), taxa real de câmbio e inflação, respectivamente. A outra hipótese é que essas variáveis possuem distribuição multinomial com média $\vec{\mu}_{t}$ e matriz de covariância condicional $\Sigma_{t}$.

A ideia dessa abordagem é estimar as médias e desvios condicionais a partir dos dados históricos das variáveis estocásticas e simular as diferentes trajetórias para a dívida. A partir dessas trajetórias, pode-se calcular, por exemplo, a probabilidade de a dívida atingir um determinado patamar em um horizonte de tempo definido a um dado nível de confiança.

Garcia e Rigobon (2004) aplica a metodologia à dívida líquida brasileira para o período de trinta meses a partir de setembro de 2002. Os resultados mostram que, embora a dívida no período pudesse ser considerada sustentável na ausência de risco, haveria muitos possíveis caminhos em que ela seria claramente insustentável. Ou seja, embora "em média" a dívida brasileira fosse então sustentável, a correlação estrutural sob a qual operava a economia brasileira colocava um enorme ponto de interrogação sobre a sustentabilidade da dívida.

Os autores também mostram que a dinâmica da dívida construída a partir dessa metodologia guarda íntima relação com o índice EMBI + Brasil ${ }^{8}$, o que evidencia sua eficácia para captar a percepção do risco sobre a dívida pública brasileira.

Mendonça et al. (2008) avalia como a administração da dívida pública no Brasil afetou a sua sustentabilidade no período de 1996-2007. Nesse contexto, os autores mostram que, a partir de 2003, o gerenciamento da dívida brasileira buscou alterar a combinação entre custo e risco, privilegiando o primeiro. Ao utilizar modelos Markov-switching para captar esta mudança de comportamento em sua administração, são feitas projeções para a dívida pública a partir de simulações de Monte Carlo. Os resultados indicam que a dívida pública brasileira pode ser considerada sustentável no médio prazo.

Mendonça et al. (2016) projetam a dívida bruta do governo geral, em percentual do PIB, para o horizonte de 24 meses com base no modelo fatorial dinâmico (MFD). Os resultados mostram que a previsão é de elevação expressiva para a dívida externa e as operações compromissadas. Os autores também estimam o efeito do endividamento sobre o crescimento da economia, concluindo que as variações da DBGG e da DLGG como proporção do PIB tiveram efeito negativo sobre a taxa de crescimento do PIB no período analisado e que, a partir da crise do subprime em 2009, esse efeito negativo se intensificou.

\footnotetext{
${ }^{8}$ O índice EMBI+ Brasil é uma medida do spread entre a taxa de retorno dos títulos da dívida brasileira e a oferecida por títulos do tesouro americano.
} 
Essa breve revisão da literatura aplicada à dívida pública brasileira permite identificar diferentes conclusões sobre a sustentabilidade da dívida pública brasileira ao longo do tempo. Em síntese, os estudos mostram que a sustentabilidade da dívida pública brasileira no período pré-estabilização era garantida pelas receitas com senhoriagem, que não podem ser associadas propriamente a um esforço fiscal por parte do governo. Para o período seguinte, as análises concluem pela sustentabilidade da dívida, em um contexto de renegociação de dívidas de entes subnacionais e de compromisso formal com a obtenção de resultados fiscais. Tal condição, no entanto, tem sido perdida nos últimos anos, na esteira da deterioração fiscal observada recentemente.

\section{Abordagem estocástica de médio prazo para a dívida pública}

A revisão da literatura sobre sustentabilidade da dívida pública mostra que a abordagem tradicional falha em gerar trajetórias para a dívida que considerem adequadamente a incerteza por trás das variáveis macroeconômicas. Quando muito, a opção é gerar cenários alternativos a determinado cenário-base ou a aplicação de testes de sensibilidade às variáveis, ambas incapazes de desenhar uma grande quantidade de possíveis trajetórias para a dívida pública.

Neste capítulo, propõe-se uma análise estocástica de médio prazo para a dívida pública brasileira que considere a incerteza intrínseca às variáveis que integram a dinâmica da dívida. Diferente da maior parte dos trabalhos existentes sobre a dívida pública brasileira, em que se analisa a dívida líquida do setor público, o objeto deste exercício será a dívida bruta do governo geral. Como visto no capítulo 2, o foco recente no endividamento líquido, simbolizado na escolha da DLSP como indicador de sustentabilidade fiscal do país, pouco revela a respeito da composição e magnitude dos ativos e passivos financeiros do governo. Para comparações internacionais, a dívida bruta é mais utilizada, o que também recomenda a análise de sua evolução.

A abordagem segue a metodologia proposta por Di Giovanni e Gardner (2008) e seguida pela Comissão Europeia em seu Relatório de Sustentabilidade Fiscal. Uma das vantagens no uso dessa metodologia é que, diferente de abordagens semelhantes (Garcia e Rigobon, 2004; Mendoza e Oviedo, 2004), ela permite que sejam construídos intervalos de 
confiança em torno de um ou mais cenários-base. No caso brasileiro, isso permitiria, por exemplo, que fosse analisado o cenário de referência do governo federal para a elaboração do Orçamento agregando-se a incerteza subjacente aos parâmetros macroeconômicos.

Em adição, a obtenção de um grande número de trajetórias para a dívida possibilita que se atribuam probabilidades aos potenciais níveis de endividamento dentro do horizonte preditivo, o que é de fácil compreensão para o usuário da informação. Por fim, o arcabouço metodológico é relativamente simples, sem o uso de modelos mais sofisticados, que em geral demandam uma quantidade maior de informações e manipulação de dados.

\subsection{Metodologia}

Neste exercício, considera-se a seguinte equação de evolução da dívida:

$$
d_{t}=\left(1+r_{t}-g_{t}\right) d_{t-1}-p_{t}
$$

Em que $d_{t}$ é a dívida bruta do governo geral em razão do PIB, $r_{t}$ é a taxa real de juros, $g_{t}$ é a taxa de crescimento real do PIB e $p_{t}$ é o resultado primário do setor público consolidado. A taxa real de juros, para cada período, é definida como:

$$
r_{t}=\frac{1+i_{t}}{1+\pi_{t}}-1
$$

Onde $i_{t}$ é a taxa nominal de juros e $\pi_{t}$ é a inflação.

A metodologia consiste na extração da estrutura dos choques nas variáveis ao longo do tempo, seguida de simulações de Monte Carlo que introduzem esses choques na equação de evolução da dívida. As simulações de Monte Carlo são realizadas duas mil vezes para o período de 2017 a 2021, permitindo que se construam intervalos de confiança em torno de um cenáriobase.

\subsubsection{Definição do cenário-base}

Em geral, o cenário-base é simplesmente a manutenção da política fiscal vigente no momento em que as previsões são feitas (unchanged policy scenario). Para o caso brasileiro, replicar os patamares atuais de taxa de juros, crescimento do PIB, receitas e despesas primárias 
resultaria muito provavelmente em trajetórias insustentáveis da dívida pública, independente da incerteza subjacente às variáveis. A análise, em último caso, restaria vazia de conclusões minimamente úteis.

Dessa forma, o cenário-base foi construído considerando a implementação de um ajuste fiscal baseado no controle do crescimento das despesas. Especificamente, o cenário-base leva em consideração uma regra fiscal de crescimento real zero das despesas primárias ${ }^{9}$. Isso permite que seja respondido, por exemplo, se, mesmo em face de um ajuste fiscal, é alta a probabilidade de que a dívida pública brasileira atinja 100\% do PIB nos próximos cinco anos. Ou a probabilidade de que a dívida, daqui a cinco anos, seja inferior ao seu patamar atual.

A hipótese central por trás do cenário-base é que o ajuste fiscal baseado no controle do crescimento do gasto, e não no aumento de receita, no médio prazo tem impacto positivo na inflação, na taxa de juros e no crescimento do PIB.

Vale dizer que as projeções nas quais serão aplicados os choques estocásticos vão de 2017 a 2021. Para 2016, embora ainda não haja dados reais para a economia, as projeções são determinísticas e se baseiam nas expectativas do mercado do final de setembro de 2016 divulgadas pelo Bacen ${ }^{10}$. No caso das receitas e despesas primárias, as projeções foram extraídas da base de dados do World Economic Outlook do FMI, cuja fonte, por sua vez, é o Ministério da Fazenda do Brasil ${ }^{11}$.

A partir de 2017, considera-se que: (i) a inflação, medida pelo IPCA, convergirá em três anos para o centro da meta e se manterá nesse patamar até 2021; (ii) haverá um novo ciclo de expansão monetária, com redução gradual da taxa Selic, de tal sorte que em 2021 a taxa real de juros esteja próxima de $4 \%$ a.a. (mais perto da média dos demais países); (iii) as receitas primárias crescerão conforme o PIB (elasticidade da receita primária em relação ao PIB unitária); (iv) as despesas primárias evoluirão conforme a inflação (crescimento real zero); e (v) o crescimento real do PIB convergirá para 2,5\% em 2019, patamar no qual se manterá até 2021.

Nessa configuração, a dívida descreve uma trajetória crescente no período, atingindo 90,6\% do PIB em 2021, mesmo considerando o ajuste fiscal e uma gradual recuperação da economia. O resultado se deve às condições iniciais da economia em 2016, com juros ainda elevados e déficits primários elevados. Dessa forma, ainda que se preveja uma regra fiscal que

\footnotetext{
9 Semelhante à regra contida na Proposta de Emenda à Constituição 241/2016, que ora tramita no Congresso Nacional.

${ }^{10}$ Disponível em: https://www3.bcb.gov.br/expectativas/publico/consulta/serieestatisticas.

${ }^{11}$ Disponível em: https://www.imf.org/external/pubs/ft/weo/2016/02/weodata/index.aspx.
} 
limite o crescimento da despesa primária, a tendência é que a reversão da trajetória da dívida apenas se observe a partir de 2022.

Tabela 2 - Hipóteses macroeconômicas - cenário-base

\begin{tabular}{lcccccc}
\hline & 2016 & 2017 & 2018 & 2019 & 2020 & 2021 \\
\cline { 2 - 7 } Selic - fim do período (\% a.a.) & 13,8 & 11,5 & 10,0 & 9,5 & 9,0 & 9,0 \\
IPCA acum. (\% a.a) & 7,2 & 5,5 & 5,0 & 4,5 & 4,5 & 4,5 \\
Crescimento real do PIB (\% a.a.) & $-3,1$ & 1,0 & 2,0 & 2,5 & 2,5 & 2,5 \\
\hline Elaboração própria. & & & & & &
\end{tabular}

Figura 5 - Evolução da dívida bruta do governo geral - Cenário-base (\% PIB)

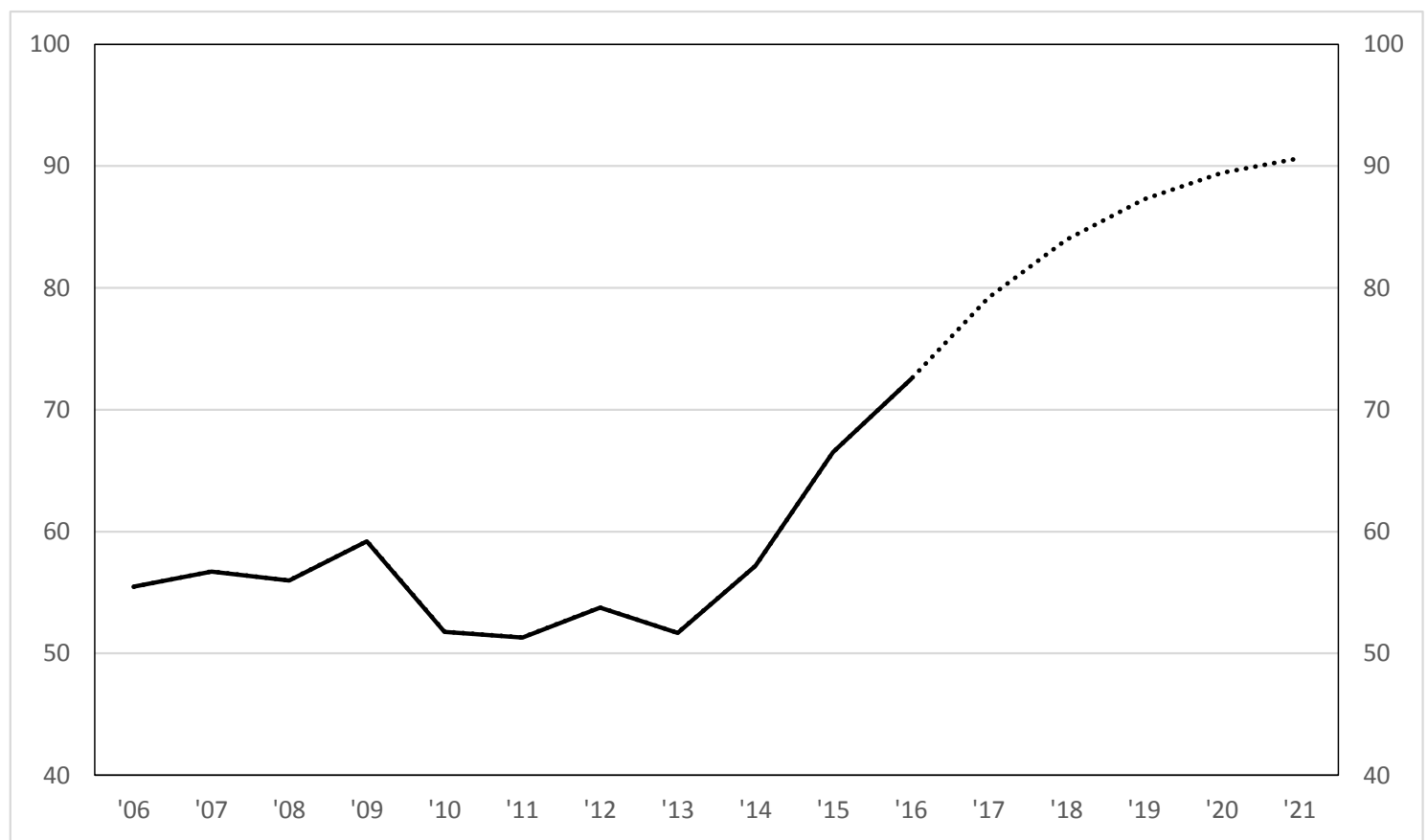

Fontes: Banco Central do Brasil, FMI (WEO database). Elaboração própria.

\subsubsection{Definição dos choques}

Os choques no PIB, na taxa de juros e na dívida são derivados da matriz de variância e covariância dos choques no período de janeiro de 2007 a julho de 2016 (115 observações mensais). A hipótese é que a volatilidade das variáveis macroeconômicas no período preditivo será similar à volatilidade observada no passado.

Para o crescimento mensal do PIB, foi utilizado como proxy o Índice de Atividade Econômica do Banco Central (IBC-Br) - com ajuste sazonal (taxa de crescimento dos últimos doze meses). As taxas mensais de juros foram obtidas a partir da taxa Selic (proxy da taxa nominal) e do índice nacional de preços ao consumidor - amplo (IPCA). 
Os choques no PIB e na taxa de juros são definidos como a primeira diferença da variável mensal:

$$
\begin{gathered}
e_{m}^{g}=g_{m}-g_{m-1} \\
e_{m}^{r}=r_{m}-r_{m-1}
\end{gathered}
$$

Vale destacar que modelar os choques na taxa de juros dessa forma, como se a variável descrevesse um caminho aleatório, é consistente com o fato de que uma raiz unitária não pode ser rejeitada na respectiva série.

O choque na dívida é definido como a diferença entre valor real da dívida e o valor que se obteria da equação da dívida usando dados observados no período (como em Garcia e Rigobon, 2004):

$$
e_{m}^{d}=d_{m}-\left(1+r_{m}-g_{m}\right) d_{m-1}+p_{m}
$$

Definir um choque para a dívida dessa forma permite que se considerem na dinâmica do endividamento bruto outros fatores além daqueles já inseridos na equação, como os ajustes patrimoniais ou mesmo a possibilidade de que resultados primários não sejam utilizados imediatamente para o pagamento da dívida. Como visto no capítulo 2, embora os ajustes patrimoniais tenham tido pouco efeito sobre a dívida bruta, no passado recente boa parte do superávit primário gerado não foi utilizado para pagamento da dívida, tendo efeito redutor apenas no endividamento líquido.

O choque no resultado primário é definido em função do choque no crescimento do PIB. Dada a elasticidade unitária em relação ao PIB, um choque no PIB provoca um choque na receita primária e consequentemente no resultado primário. A despesa primária, por outro lado, não é afetada pelo crescimento do PIB, tendo em vista que para ela vigora a regra de crescimento real zero no horizonte preditivo.

A tabela a seguir apresenta a variância e a covariância dos choques sobre o crescimento real do PIB, a taxa real de juros e a dívida.

Tabela 3 - Matriz de variância e covariância dos choques

\begin{tabular}{lccc}
\hline & Cresc. real do PIB & Taxa real de juros & Dívida \\
\hline Cresc. real do PIB & 1,25 & - & - \\
Taxa real de juros & $-0,05$ & 0,15 & - \\
Dívida & 0,24 & $-0,04$ & 0,64 \\
\hline
\end{tabular}




\subsubsection{Simulações de Monte Carlo}

De posse da matriz de variância e covariância dos choques, parte-se para a obtenção dos diferentes caminhos para a dívida, conforme os passos a seguir:

(i) Geração de vetores aleatórios de choques mensais para o período de 2017 a 2021. Os choques, por hipótese, têm distribuição normal conjunta com média zero e matriz de variância e covariância idêntica à dos choques passados;

(ii) Agregação dos choques mensais em choques anuais. Os choques no crescimento do PIB $(g)$, na taxa real de juros ( $r$ ) e na dívida no ano $t$ são dados pela soma dos choques mensais. Quanto à agregação de choques para a taxa de juros, os trabalhos em geral permitem que os choques sejam carregados para os anos seguintes de acordo com seu prazo médio de maturidade. Isso pressupõe que os títulos emitidos sejam prefixados, o que se aplica a apenas uma pequena parcela da dívida pública brasileira. Daí porque optamos por desconsiderar a abordagem normalmente adotada neste exercício e modelar choques anuais na taxa de juros da mesma forma que os choques no crescimento e na dívida:

$$
\varepsilon_{t}^{g, r, d}=\sum_{m=1}^{12} \varepsilon_{m}^{g, r, d}
$$

(iii) Cálculo das distribuições para $r, g$ e $p$, conforme os choques calculados em (ii), considerando duas hipóteses distintas:

a. Choques temporários no crescimento (e, portanto, no resultado primário) e na taxa real de juros. Nesse caso, choques anuais são aplicados a cada ano sobre os valores do cenário-base para as variáveis:

$$
\begin{aligned}
& g_{t}=\bar{g}_{t}+\varepsilon_{t}^{g} \\
& r_{t}=\bar{r}_{t}+\varepsilon_{t}^{r}
\end{aligned}
$$

Onde $\bar{g}_{t}$ e $\bar{r}_{t}$ são os valores do cenário-base para $g$ e $r$ no ano $t$

b. Choques temporários no crescimento (e, portanto, no resultado primário), mas choques permanentes na taxa real de juros. Dessa forma, a partir de 2018 a taxa de juros em t é função da taxa de juros em t-1:

$$
\begin{aligned}
& g_{t}=\bar{g}_{t}+\varepsilon_{t}^{g} \\
& r_{t}=\left\{\begin{array}{c}
\bar{r}_{t}+\varepsilon_{t}^{r}, \quad \text { se } t=2017 \\
r_{t-1}+\varepsilon_{t}^{r}, \quad \text { se } t \geq 2018
\end{array}\right.
\end{aligned}
$$


(iv) Usando os valores obtidos em (iii), cálculo da trajetória da dívida para o período de 2017 a 2021.

(v) Repetir os passos (i) a (iv) duas mil vezes e extrair percentis dos valores de $d$, a partir dos quais são construídos os intervalos de confiança para o período de 2017 a 2021 sob as hipóteses de choques temporários e permanentes na taxa real de juros.

\subsection{Resultados}

Como visto, as projeções estocásticas resultam em uma distribuição de caminhos para a dívida bruta em torno de um cenário-base, que correspondem a um amplo conjunto de possíveis condições macroeconômicas subjacentes.

A melhor forma de ilustrar os resultados das projeções estocásticas é por meio de fan charts, que representam o cone da distribuição da relação dívida/PIB ao longo do horizonte preditivo, destacando os percentis de interesse dessa distribuição. Os gráficos a seguir reportam os resultados das simulações sob as hipóteses de choques temporários e permanentes.

Figura 6 - Projeções para a dívida bruta do governo geral - choques temporários

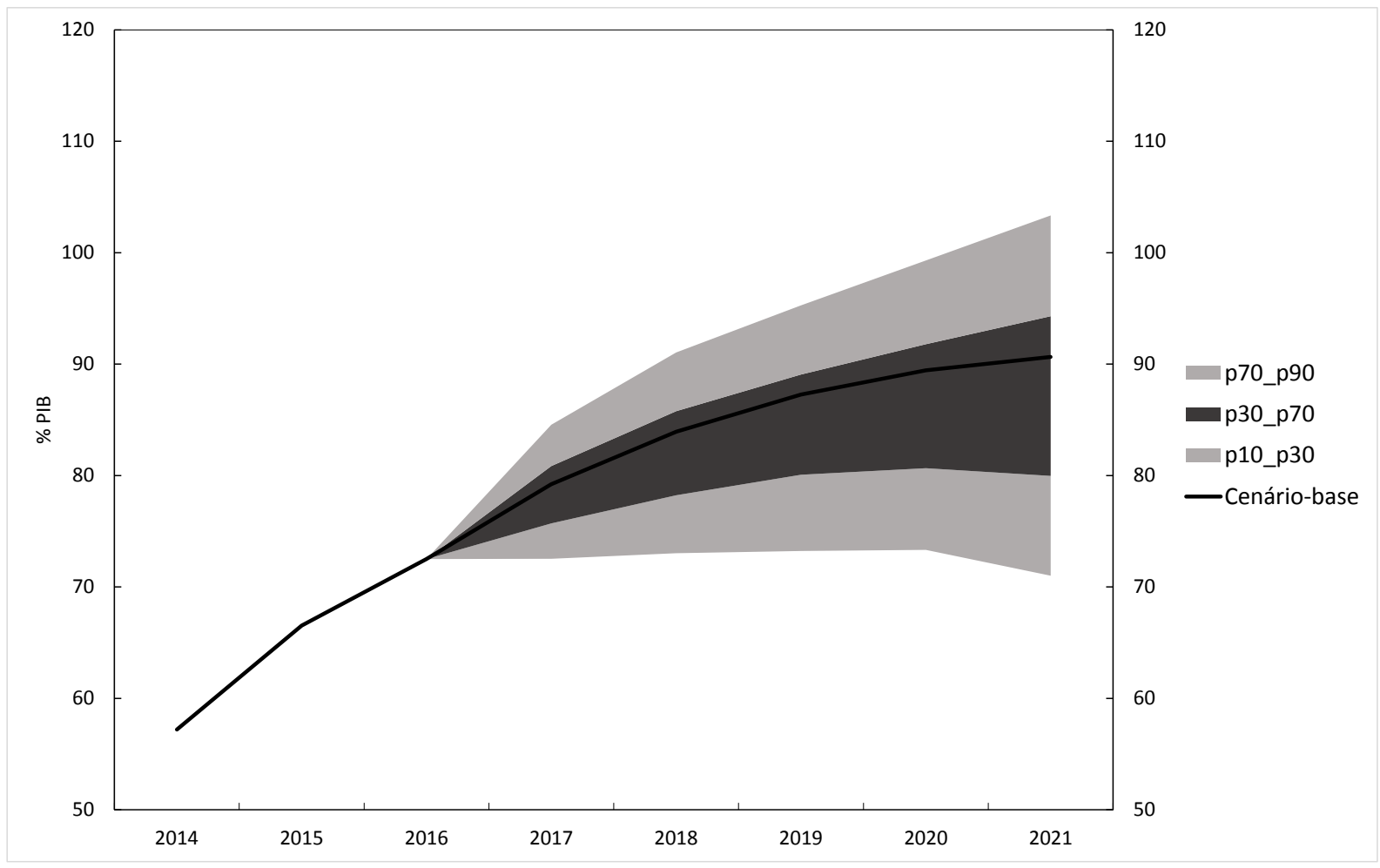


Figura 7 - Projeções para a dívida bruta do governo geral - choques permanentes

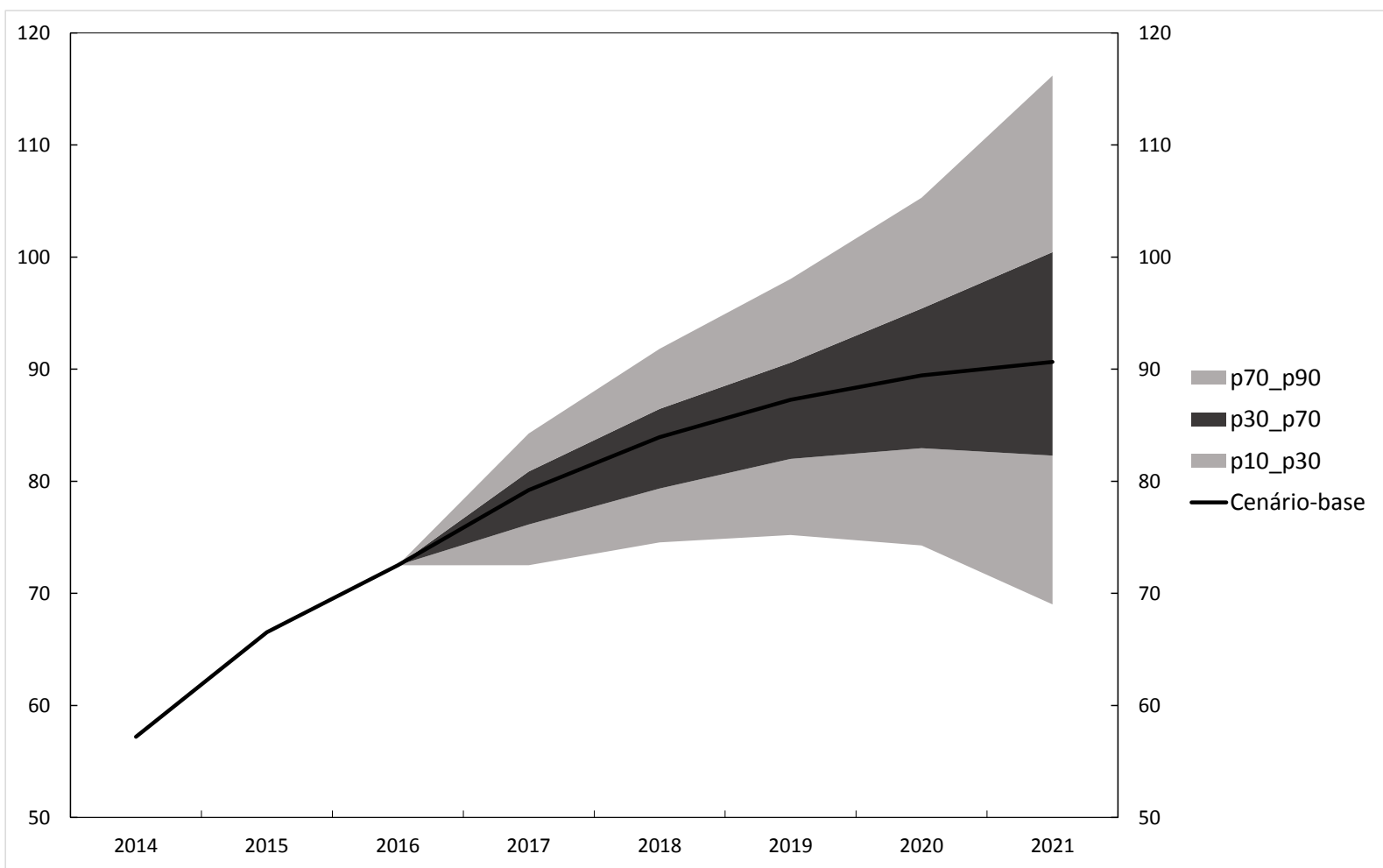

Como se observa, sob a hipótese de choques permanentes na taxa real de juros, o desvio padrão das projeções é significativamente maior. Segundo Di Giovanni e Gardner (2008), as propriedades de raiz unitária da série mensal da taxa de juros sugerem que a hipótese dos choques permanentes pode se aproximar mais do verdadeiro processo estocástico por trás da trajetória da dívida. Por outro lado, a ausência de reversão à media no caso dos choques permanentes produz uma distribuição de taxas de juros irrealista nos períodos mais distantes. Para os autores, o verdadeiro processo estocástico provavelmente se situa entre esses dois casos extremos: há provavelmente mais permanência nos choques na taxa de juros do que a hipótese dos choques temporários permitem, mas também deve haver alguma reversão à média, o que não se observa sob a hipótese de choques permanentes.

No fan chart, a trajetória da dívida sob as hipóteses do cenário-base é mostrada pela linha sólida próxima ao centro do cone. O cone cobre $80 \%$ de todos os resultados para a dívida bruta após simularmos dois mil possíveis comportamentos do crescimento do PIB, da taxa real de juros, do resultado primário e dos choques na dívida ao longo do período projetado. As linhas superior e inferior delimitam respectivamente o $10^{\circ}$ e o $90^{\circ}$ percentis da distribuição. As áreas sombreadas representam diferentes porções da distribuição, conforme os percentis especificados. 
A diferença entre o $10^{\circ}$ e o $90^{\circ}$ percentis da distribuição da dívida em 2021 é de 32,3 p.p., o que evidencia o grau de incerteza por trás das variáveis macroeconômicas. Sob a hipóteses de choques permanentes na taxa real de juros, esse intervalo é ainda maior, 47,2 p.p.

Sob a hipótese de choques temporários, a probabilidade de que a relação DBGG/PIB em 2021 seja superior ao seu patamar em 2016 é de 87,6\%. A probabilidade de que ela supere $100 \%$ do PIB ao final do período é de $15 \%$. Sob a hipótese de choques permanentes, esta probabilidade chega a $30,8 \%$, enquanto que a probabilidade de aumento da dívida seria de $86,4 \%$.

A tabela abaixo resume algumas das informações de interesse, sob as duas hipóteses.

Tabela 4 - Alguns resultados das projeções estocásticas - 2021

\begin{tabular}{|c|c|c|c|c|c|c|c|}
\hline & \multirow[b]{2}{*}{$\begin{array}{c}\text { Dívida } \\
\text { em } 2016 \\
\text { (\% PIB) }\end{array}$} & \multicolumn{6}{|c|}{ Dívida em 2021} \\
\hline & & $\begin{array}{l}\text { Projeção } \\
\text { mediana }\end{array}$ & $\begin{array}{c}10^{\circ} \\
\text { percentil }\end{array}$ & $\begin{array}{c}90 \\
\text { percentil }\end{array}$ & $\begin{array}{l}\text { Diferença } \\
\text { entre } 10 \text { o e } \\
\text { 90o perc. } \\
\text { (p.p.) }\end{array}$ & $\begin{array}{l}\text { Probabilidade da } \\
\text { dívida em } 2021 \\
\text { ser maior do que } \\
\text { em } 2016(\%)\end{array}$ & $\begin{array}{l}\text { Probabilidade da } \\
\text { dívida em } 2021 \\
\text { ser maior do que } \\
100 \% \text { do PIB (\%) }\end{array}$ \\
\hline Choques temporários & 72,5 & 86,4 & 71,0 & 103,3 & 32,3 & 87,6 & 15 \\
\hline Choques permanentes & 72,5 & 91,6 & 69,0 & 116,2 & 47,2 & 86,4 & 30,8 \\
\hline
\end{tabular}

Em resumo, as projeções estocásticas para a dívida bruta do governo geral mostram que, ainda que se considere a possibilidade de um ajuste fiscal, em particular um ajuste baseado no controle do crescimento da despesa primária, há uma probabilidade muito baixa de que o endividamento bruto reverta sua trajetória de crescimento nos próximos anos. Se, por um lado, esse resultado possa colocar frear algum otimismo em relação a efeitos de curto prazo do ajuste fiscal, por outro, evidencia que de fato a postura fiscal dos últimos anos se tornou insustentável. 


\section{Conclusões}

O presente estudo buscou avaliar a sustentabilidade da dívida pública brasileira no médio prazo, com base em projeções estocásticas para o comportamento das principais variáveis que afetam a dinâmica da dívida.

De início, o trabalho explorou alguns aspectos relacionados à evolução recente da dívida pública brasileira. Essa análise foi importante por pelo menos dois motivos. Em primeiro lugar, reforçou a necessidade de um olhar mais atento à dinâmica da dívida bruta, principal indicador de sustentabilidade para efeito de comparação internacional. A condução da política fiscal até 2013 foi capaz de reduzir o endividamento líquido sem que tal impacto se verificasse na dívida bruta. Além disso, o foco exclusivo na dívida líquida não revela adequadamente as mudanças de composição e magnitude dos ativos e passivos do setor público.

Em segundo lugar, expôs os principais fatores condicionantes do endividamento. Em especial, mostrou que, embora no caso da dívida líquida, os ajustes patrimoniais e metodológicos desempenharam papel importante no passado recente, especialmente os ajustes derivados do câmbio, no caso da dívida bruta os ajustes têm tido efeito limitado. A análise também mostrou que nos últimos anos boa parte dos superávits primários não foi utilizada para o pagamento da dívida, o que teve que ser considerado ao se modelarem os choques que afetam a dinâmica da dívida bruta.

Em seguida, a revisão da literatura sobre sustentabilidade fiscal apresentou as diferentes abordagens a respeito do tema. Foram sublinhadas as limitações da abordagem tradicional, particularmente o fato de não considerar adequadamente a incerteza subjacente ao comportamento das variáveis macroeconômicas.

A abordagem aqui adotada busca justamente superar essa limitação ao introduzir a possibilidade de que as variáveis que afetam a dinâmica da dívida estejam sujeitas a choques estocásticos construídos a partir de dados históricos. Essa abordagem tem a vantagem adicional de se permitir que a análise seja estruturada em torno de um cenário-base independente, ao invés da extração direta do valor das variáveis ao longo do período preditivo. Essa possibilidade parece cair bem no contexto brasileiro atual, dado que as condições fiscais de momento levam claramente a trajetórias insustentáveis da dívida.

Alternativamente, pode-se pensar na aplicação da metodologia sobre o cenário macroeconômico de referência do governo federal, que orienta a elaboração do Orçamento da 
União, permitindo assim que se construam intervalos de confiança em torno das projeções oficiais.

Outra vantagem é a comunicabilidade dos resultados. Com efeito, as principais conclusões a partir dessa abordagem derivam da possibilidade de se atribuírem probabilidades para os possíveis níveis de endividamento dentro de um horizonte preditivo, o que costuma ser de fácil compreensão aos usuários da informação.

A metodologia também tem suas limitações. Embora as propriedades de raiz unitária da série mensal da taxa de juros sugiram que os choques permanentes se aproximam mais do verdadeiro processo estocástico da dívida, a ausência de reversão à media nesse caso produz distribuições de taxas de juros irrealistas em períodos mais distantes. Outra limitação é que os choques no resultado primário derivam exclusivamente dos choques no produto sobre a receita primária e não de uma função de reação fiscal endogenamente determinada, o que permitiria, por exemplo, modelar medidas fiscais de estabilização em face de um choque negativo no PIB ou na taxa de juros.

Os resultados mostram que, mesmo em face de um ajuste fiscal e da recuperação gradual da economia, a probabilidade de que em 2021 a dívida seja superior ao patamar de 2016 é de $87,6 \%$, enquanto que a probabilidade de que nesse período a dívida ultrapasse $100 \%$ do PIB é de $15 \%$. Sob a hipótese de choques permanentes na taxa real de juros, a probabilidade de crescimento da dívida continua alta, $86,4 \%$, ao passo que a probabilidade de que ela extrapole os $100 \%$ do PIB chega a $30,8 \%$. 


\section{Referências Bibliográficas}

AFONSO, Antonio. Fiscal sustainability: The unpleasant European case. FinanzArchiv: Public Finance Analysis, v. 61, n. 1, p. 19-44, 2005.

ALMEIDA, M. Impacto fiscal da relação entre Tesouro Nacional e BNDES. Rio de Janeiro: Ipea, nov. 2009. Nota técnica.

BAGNAI, Alberto. Keynesian and neoclassical fiscal sustainability indicators, with applications to EMU member countries. Available at SSRN 620042, 2004.

BANCO CENTRAL DO BRASIL (BACEN). Tabelas especiais: dívida líquida e bruta do governo geral e necessidades de financiamento do setor público. Disponível em: <http://www.bcb.gov.br/?SERIEDLSP>. Acesso em: 6/6/2016.

. Manual de Estatísticas Fiscais. Abril/2012. Disponível em: <http://www.bcb.gov.br/ftp/infecon/Estatisticasfiscais.pdf $\rangle$. Acesso em: 10/6/2016.

correlatos". Nota Depec-Bacen. 2015.

BARNHILL, Mr Theodore M.; KOPITS, Mr George. Assessing Fiscal Sustainability Under Uncertainity. International Monetary Fund, 2003.

BARRO, Robert J. On the determination of the public debt. The Journal of Political Economy, p. 940-971, 1979.

BERTI, Katia. Stochastic public debt projections using the historical variance-covariance matrix approach for EU countries. Economic papers, n. 480, p. 1-25, 2013.

BEYNET, Pierre; PAVIOT, Edouard. Assessing the sensitivity of Hungarian debt sustainability to macroeconomic shocks under two fiscal policy reactions. 2012.

BICALHO, Aurélio. Teste de sustentabilidade e ajuste fiscal no Brasil pós-Real. 2005.

BLANCHARD, Olivier J. et al. The sustainability of fiscal policy: New answers to an old question. NBER Working Paper, n. R1547, 1991.

BLANCHARD, Olivier Jean et al. Suggestions for a New Set of Fiscal Indicators. OECD Publishing, 1990.

BOHN, Henning. The behavior of US public debt and deficits. Quarterly journal of economics, p. 949-963, 1998.

BOHN, Henning. The Sustainability of Fiscal Policy in the United States. SSRN Working Paper Series, 2005.

BUITER, Willem H. A guide to public sector debt and deficits. Economic policy, v. 1, n. 1, p. 13-61, 1985. 
COMISSÃO EUROPEIA. Fiscal Sustainability Report. European Economy Institutional Paper 18. 2016.

CONGRESSIONAL BUDGET OFFICE. The long-term budget outlook. Washington, DC: CBO, 2015.

COTTARRELI, C.; MOGHADAM, R. Modernizing the Framework for Fiscal Policy and Public Debt Sustainability Analysis. IMF, August, v. 5, p. 2011, 2011.

CHICOLI, Raí Da Silva. Sustentabilidade da dívida pública brasileira: uma análise sob diversos conceitos de superávit primário e endividamento. 2016. Tese de Doutorado. Universidade de São Paulo.

DE MELLO, Luiz. Estimating a Fiscal Reaction Function: The Case of Debt Sustainability in Brazil. OECD Publishing, 2005.

D'ERASMO, Pablo; MENDOZA, Enrique G.; ZHANG, Jing. What is a sustainable public debt?. National Bureau of Economic Research, 2015.

GARDNER, E. H.; DI GIOVANNI, Julian. A Simple Stochastic Approach to Debt Sustainability Applied to Lebanon. International Monetary Fund, 2008.

FERREIRA, Carlos Kawall Leal. A dinâmica da dívida bruta e a relação Tesouro-Banco Central. 2016.

FUNDO MONETÁRIO INTERNACIONAL. World Economic Outlook Database. Abril/2014. World Economic Outlook: Public Debt in Emerging Markets. 2003.

GARCIA, Márcio; RIGOBON, Roberto. A risk management approach to emerging market's sovereign debt sustainability with an application to Brazilian data. National Bureau of Economic Research, 2004.

GIULIANO, Fernando; SANDLERIS, Guido. Sovereign Debt in Latin America and the Caribbean: An Analysis of its Composition and Sustainability. Inter-American Development Bank, 2010.

GOBETTI, Sérgio Wulff; SCHETTINI, Bernardo Patta. Dívida líquida e dívida bruta: uma abordagem integrada para analisar a trajetória e o custo do endividamento brasileiro. 2010.

GOLDFAJN, Ilan; GUARDIA, Eduardo Refinetti. Fiscal Rules and Debt Sustainability in Brazil. Banco Central do Brasil Technical Note, v. 39, 2003.

HAKKIO, Craig S.; RUSH, Mark. Is the budget deficit "too large?". Economic inquiry, v. 29, n. 3, p. 429-445, 1991.

ISLLER, J. V.; LIMA, L. R. Public debt sustainability and endogenous seignorage in Brazil: time-series evidence from 1947-92. Ensaios Econômicos da EPGE, v. 306, 1997.

LUPORINI, Viviane. Sustainability of the Brazilian fiscal policy and central bank independence. Revista brasileira de economia, v. 54, n. 2, p. 201-226, 2000. 
LUPORINI, Viviane et al. The behavior of the Brazilian federal domestic debt. Cedeplar, Universidade Federal de Minas Gerais, 2001.

LUPORINI, Viviane. Sustainability of Brazilian fiscal policy, once again: corrective policy response over time. Estudos Econômicos (São Paulo), v. 45, n. 2, p. 437-458, 2015.

MENDES, M. J. A Lei 11.803/2008 e a Relação Financeira Tesouro - Banco Central. Brasília: Núcleo de Estudos e Pesquisas/CONLEG/Senado, Fevereiro/2016 (Texto para Discussão no 189).

MENDONÇA, Mário Jorge et al. Um estudo sobre o endividamento público no Brasil e implicações. Ipea. Texto para discussão nº 2197. Rio de Janeiro, maio de 2016.

MENDONÇA, Mário Jorge Cardoso de; SANTOS, Cláudio Hamilton Matos dos; SACHSIDA, Adolfo. Revisitando a função de reação fiscal no Brasil pós-Real: uma abordagem de mudanças de regime. Estudos Econômicos (São Paulo), v. 39, n. 4, p. 873-894, 2009.

O'CONNELL, Stephen A.; ZELDES, Stephen P. Rational ponzi games. International Economic Review, p. 431-450, 1988.

OSTRY, Jonathan David et al. Fiscal space. International Monetary Fund, Research Department, 2010.

PELLEGRINI, J. A. Dívida bruta e ativo do setor público: o que a queda da dívida líquida não mostra? Brasília: Núcleo de Estudos e Pesquisas do Senado, Junho/2011 (Texto para Discussão $\mathrm{n}^{\circ}$ 95). 2011.

ROCHA, Fabiana. Long-run limits on the Brazilian government debt. Revista brasileira de economia, v. 51, n. 4, p. 447-470, 1997.

SARVI, Tuukka et al. Some approaches for assessing the sustainability of public finances. 2011.

SCHETTINI, B. P. A dinâmica recente do endividamento público e das despesas de juros. In: SANTOS, C. H. M. dos; GOUVÊA, R. R. (Org.). Finanças públicas e macroeconomia no Brasil: um registro da reflexão do Ipea (2008-2014). Brasília: Ipea, 2014. v. 2.

SILVA, Roseli da; GAMBOA, Ulisses Ruiz de. Regime fiscal e sustentabilidade da dívida pública brasileira-1986 a 2006. Revista Gestão \& Políticas Públicas, v. 1, n. 1, 2011.

SIMONASSI, Andrei G.; ARRAES, R. A. Função de resposta fiscal, múltiplas quebras estruturais e a sustentabilidade da dívida pública no Brasil. Anais do Encontro Nacional de Economia da ANPEC, Recife-PE, 2007.

TESOURO NACIONAL. Boletim de Subsídios do Tesouro Nacional ao BNDES e à FINEP, $2^{\circ}$ bimestre de 2016. Disponível em: < http://www.tesouro.fazenda.gov.br/-/subsidios-dotesouro-nacional-ao-bndes $>$. Acesso em: 15/6/2016.

TREHAN, Bharat; WALSH, Carl E. Common trends, the government's budget constraint, and revenue smoothing. Journal of Economic Dynamics and Control, v. 12, n. 2, p. 425-444, 1988. 
TREHAN, Bharat; WALSH, Carl E. Testing intertemporal budget constraints: Theory and applications to US federal budget and current account deficits. Journal of Money, Credit and banking, v. 23, n. 2, p. 206-223, 1991.

WILCOX, David W. The sustainability of government deficits: Implications of the presentvalue borrowing constraint. Journal of Money, credit and Banking, v. 21, n. 3, p. 291-306, 1989. 